\title{
O CRISTIANISMO. O DIREITO CANÔNICO
}

\author{
THE CHRISTIANISM. THE CANON LAW
}

\section{Antonio Augusto Machado de Campos Neto*}

\begin{abstract}
Resumo:
A Religião cristã é baseada na Vida e nos Ensinamentos de Jesus Cristo e quase tudo o que se sabe sobre Ele está contido nos quatro primeiros livros do Novo Testamento da Bíblia, a saber, Evangelhos de Mateus, Marcos, Lucano, apelidado Lucas, e João. Esses quatro discípulos narram os anos de Sua pregação na Galiléia como, também, descrevem Sua morte e Ressurreição. E a ressurreição é a mais importante no enredo de todas as histórias, uma vez cristãos acreditarem que, ao sacrificar o Seu Filho, Deus lhes trouxera a salvação e a oportunidade de uma vida eterna. Da Religião nasce o Direito e a Ética; a História da Religião é a história do homem na busca de quanto mais se organizarem melhor será a vida. A mãe Religião necessitava de aperfeiçoamento: o filho Direito e o homem, homo sapiens, nessa busca de produção, industrialização, relações econômico-sociais procurou entendê-lo e aperfeiçoá-lo. $\mathrm{Na}$ Doutrina hebraica - origem do Cristianismo - o Direito é desde logo imutável e só Deus pode modificá-lo; idéia fundamental do Direito Canônico ou Eclesial que, segundo o Papa Paulo VI, se embasa no conceito de sociedade perfeita que traduzimos por sociedade soberana ou independente e no princípio jurídico $u b i$ societas ibi ius.
\end{abstract}

Palavras-chave: Cristianismo. Templários. Cruzadas. Catolicismo. O Papa. Direito e Código Canônico.

\begin{abstract}
:
The Christian religion is based on Life and Teachings of Jesus Christ and almost everything we know about Him is contained in the first four New Testament books of the Bible, namely, the Gospels of Matthew, Mark, Lucan, nickname of Luke and John for disciples. Those four disciples tell the years of his preaching in Galilee, as well as, describing His death and resurrection. And the resurrection is the most important of all stories, since Christians believe that by sacrificing His Son, God brought them to salvation and an opportunity of an eternal life. From Religion borns the Law and Ethics, the History of Religion is the history of man in search of much more to organize better the life. The mother Religion needed improvement: the son Law and man, homo sapiens, in this quest of production, industrialization, economic-social relation aimed to understand it and improve it. In hebrew Doctrine - the Cristianism derives from that - the Law is unchangeable and only God can change; fundamental idea of Ecclesiastical or CanonLaw and your nature, under Pope Paul VI, is based on the concept of a perfect society that we translate as sovereign and independent society and the legal principle $u b i$ societas ibi ius.
\end{abstract}

Chefe do Serviço Técnico de Imprensa da Faculdade de Direito da Universidade de São Paulo. Editor da Revista da Faculdade de Direito da Universidade de São Paulo. Bacharel em Jornalismo pela Faculdade de Comunicação Social Cásper Líbero. Bacharel em Direito pela Faculdade de Direito da Universidade de São Paulo. 
Keywords: Christianity. Templar. Crusades. Catholicism. The Pope. Law and Code of Canon Law.

"Qualquer que seja a atitude diante do Cristianismo, não se pode deixar de considerá-lo como um dos fenômenos da Humanidade. O fato de que a Igreja cristã haja perdurado cerca de dois milênios e ainda permaneça cheia de vigor e, em muitos países, mais poderosa que o Estado, não pode deixar de provocar enorme admiração. Assim, tudo o que possa contribuir para a compreensão desse colossal fenômeno e o estudo das origens dessa organização, tem extrema importância, atualidade e significação prática"

Karl Kautsky

"Não penseis que vim destruir a lei e os profetas; não vim para destrui-los, mas para dar-lhes cumprimento. Porque em verdade vos digo que o Céu e a Terra não passarão, até que não se cumpra tudo quanto está na lei, até o último jota e o último ponto".

Mateus, $V: 17-18$

“... há quem quereria que a Igreja fosse só espiritual e, portanto, invisivel; para quem pensa assim, só essa Igreja seria de origem divina sem levar em conta, de nenhum modo, a conseqüencia lógica de que uma Igreja invisivel não é Igreja. A Igreja, pelo contrário, é precisamente uma sociedade jurídica, organizada, visivel, perfeita".

Papa Paulo VI

1. Introdução. A Religião

No conjunto das religiões reveladas, encabeçado pelo Judaísmo e seus prolongamentos Cristianismo, Islamismo e Espiritismo , nota-se que o Direito e a Ética derivam da Religião. Cumpre salientar que as normas de conduta, éticas e legais, eram estipuladas pelos deuses e executadas por sacerdotes, dando margem aos julgamentos realizados por eles - da conduta dos povos, sob o domínio de normas jurídicas, as quais eram editadas por Deus como, também, pelos deuses. É cristalino que tanto a Lei de Deus quanto a Lei do homem exigem diversos cumprimentos, sob pena de aplicação de severas sanções. Todavia, há nítida distinção, porque as leis humanas são evoluídas com o passar dos tempos e a Lei Divina nunca muda, é imutável, porque o seu Autor Legislador é o Pai Todo-Poderoso que também é chamado de Javé, Deus ou Alá. 
E assim, o Direito prescinde das religiões. E é da vida em sociedade que segue o Direito. O Direito é testemunho dos tempos, advindo, por exemplo, dos Dez Mandamentos ou Decálogo que, no Cristianismo, a Humanidade tem até hoje máximo respeito. As religiões têm evoluído em circunstâncias de incessantes trabalhos, cujo intuito é o de coibir determinados comportamentos não-aprovados socialmente, acarretando dualismo no interior do sistema social que é o de se apresentar ao homem o discernimento entre o Bem, ao encontro de Deus, e o Mal, ao encontro do Príncipe do Mal. E interessante lembrar que o catolicismo da Inquisição, de perfil extremamente exagerado aos padrões atuais, era respaldado no poder político. No âmbito do Islamismo, os aiatolás pensam em governar em nome de Alá, aplicando os mandamentos do Qur'an e da châr'ia muçulmana em lugar dos códigos laicos. E assim a Religião tem o desempenho de atuar a partir de sanções prometidas nesta encarnação ou post-mortem.

Uma das maiores evidências na diferenciação entre Religião e Direito é a de que a primeira é mítica, no sentido de que sua gênese é totalmente não-verdadeira e o Direito é imanente. Ressalta-se que o catolicismo, advindo da Mitologia palestina, deu margem ao andar das carruagens guiadas, severamente, pelos imperadores romanos. $\mathrm{O}$ glorioso Império romano, por meio da Igreja católica, continuou a viver em outros termos e Constantinopla (hoje Istambul) só desapareceu em 1453, época das grandes descobertas por meio da navegação portuguesa e espanhola e do Renascimento italiano.

Na História das Religiões, bem diferenciado no conteúdo de enredo, o Islamismo nasceu junto do poderio muçulmano; ser devoto do Islamismo é dever tanto do civil quanto do militar e todos pertencentes às ordens de Alá; como no Judaísmo, Alá é Javé a instruir o Povo de Deus; no Islamismo, Mohammad é o profeta instrutor, por meio do Anjo Gabriel. No Judaísmo clássico, Javé é o centro, o imo da visão judaica do homem e do Universo. No Cristianismo que floresceu da crisálida judaica o centro são os apóstolos, como Paulo, que aos sacrifícios atingiram como aceitação a maior parte dos homens, deste planeta. O Espiritismo veio alicerçar os ensinamentos do Filho de Deus por meio dos Espíritos comunicantes, tendo como elo o professor Léon Hippolyte Denizard Rivail, que adotou o nome Allan Kardec, homônimo de um Espírito iluminado que com ele se comunicava.

Da Religião nasce o Direito e a Ética; a História da Religião é a história do homem na busca de quanto mais se organizarem melhor será a vida. Nesta evolução, enfatizando ao acaso o Direito do Trabalho ou Internacional, os valores surgem em crescendo animador, estudado pelos jurisconsultos, porque não se poderia aplicar, nos dias de hoje, os preceitos jurídicos da velha Atenas ou da antiga Roma. Em Roma houve período que não se distinguia os direitos divinos (fas) dos direitos do homem. E assim, a mãe Religião necessitava de aperfeiçoamento: o filho Direito. O homem, homo sapiens, 
nessa busca de produção, da industrialização, das relações econômico-sociais procurou entendê-lo e aperfeiçoá-lo.

O Cristianismo tem como premissa maior a de que os cristãos acreditam que Jesus ${ }^{1}$ é o Filho de Deus, cuja vinda havia sido prometida na Bíblia, ${ }^{2}$ especificamente no Velho Testamento. Além disso, premissa menor, sustenta que a Humanidade vivia em pecado desde que Adão e Eva desobedeceram a Deus e creem, premissa final, que Jesus, por meio de sua Vida, Mente e Ressurreição, trouxera a seus seguidores a redenção desse pecado original. A Sua vinda foi tão marcante que, desde o seu nascimento, ano 1, é registrada a Era Cristã, sendo que a cronologia histórica se divide em antes de Cristo e depois de Cristo.

A Religião cristã é baseada na Sua Vida e Seus Ensinamentos e quase tudo o que se sabe sobre Jesus está contido nos quatro primeiros livros do Novo Testamento da Bíblia: os Evangelhos de Mateus, Marcos, Lucano - apelido Lucas - e João. Esses quatro homens, discípulos de Cristo, narram os anos de sua pregação na Galiléia como, também, descrevem sua morte e Ressurreição; a mais importante de todas as histórias, uma vez os cristãos acreditarem que, ao sacrificar Seu Filho, Deus lhes trouxera a salvação e a oportunidade de uma vida eterna.

Jesus nasceu em Belém, durante o Reinado de Herodes, aproximadamente em torno do ano 4 a.C. Era filho de José e Maria. O Livro de Lucas, apelido de Lucano, narra que o Anjo Gabriel visitou Maria e lhe contou que ela encontrara graças, diante de Deus, e que daria à luz o Filho Dele, o qual deveria chamá-lo de Jesus. Essa visita é conhecida como Anunciação. Maria é nascida em Jerusalém ou Sefóris e foi criada em Nazaré. À época do nascimento de Jesus, ela era prometida do carpinteiro José, descendente do Rei David. O imperador romano, segundo os livros de Mateus e de Lucas, resolvera convocar todos os moradores da Judéia - no intuito de coletar impostos e registrar as pessoas e suas propriedades - para um Censo; por causa disso, José e Maria seguiram para Belém, uma cidade rural ao Norte da Palestina e terra de José. Nela, nasceu Jesus. Por ser uma localização ruralista, não havia quartos disponíveis nas estalagens. E assim, por esse motivo, o casal se acomodara em estábulo, sendo o local do nascimento do menino. A Judéia que pertencia ao Império Romano, atualmente ocupada pela Síria e Israel, açambarcava tanto Jerusalém quanto a Galiléia e a Palestina. Os livros de Mateus contam que um grupo de sábios do Oriente, ou Reis Magos, seguiu uma estrela até encontrar o menino Jesus. Eles veneraram o bebê e fizeram-lhe preciosas oferendas de ouro, incenso e mirra. E também que logo após o nascimento de Jesus, um Anjo foi até a um grupo de pastores nos campos ao arredor de Belém e lhes falou do Nascimento do Salvador; os pastores foram os primeiros a visitar a criança no estábulo.

2 A Bíblia cristã é dividida em duas seções: o Velho Testamento consiste principalmente nos escritos hebraicos, que constituem o corpo da Religião judaica e o Novo Testamento formado por textos em idioma grego, os quais tratam da Vida de Jesus e do Cristianismo primitivo, coligados pelos primeiros cristãos. Cumpre salientar que o Velho Testamento narra a história do Povo israelita, da Criação do Universo até o século II a.C. Inclui também escritos dos profetas judeus que os cristãos primitivos interpretavam como presságios da vinda de Jesus Cristo. O Novo Testamento é constituído pelos escritos dos primeiros cristãos no século III d.C. que coligaram seus ensinamentos vividos junto de Jesus e são os quatro Evangelhos, os Anos dos Apóstolos que descrevem a sua atuação depois da ascensão, compondo coleção de epístolas e o Apocalipse. Historiadores e pesquisadores em sua maioria acreditam que os primeiros cinco livros do Velho Testamento foram escritos por Moisés. A autenticidade de certos livros do Velho Testamento, conhecidos como Apócrifos, foi questionada por várias correntes da Igreja e por isso eles são impressos in separata. 


\section{Reencarnação. O Sermão da Montanha e os milagres}

Segundo o Cristianismo, Deus veio a este planeta sob a forma de Jesus Cristo e o feito é conhecido como Doutrina da Encarnação. Aqui, Ele viveu como homem e teve de enfrentar problemas humanos como o sofrimento e a dúvida. Porém, como Deus em forma humana, Jesus também tinha poderes especiais, usando-os para auxiliar os seres humanos. Ele curava os doentes e ressuscitava os mortos.

Jesus cresceu na região da Galiléia, ao Norte da Palestina; foi educado em uma sinagoga e também aprendera a profissão de carpinteiro ensinada pelo seu pai José ${ }^{3} \mathrm{e}$ começara a pregar e a ensinar na Galiléia aos 30 anos de idade. Jesus expôs muitos de seus ensinamentos centrais em Sermão que, segundo a descrição de Mateus, foi pregado numa montanha (Sermão da Montanha). O Sermão começa com série de bênçãos dirigidas aos pobres de espírito, aos mansos e aos misericordiosos, entre outros. Ensina também aos fiéis obedecerem às leis de Deus; dentre elas, a de amar a seus inimigos e a não se preocupar com as coisas materiais. E se tornou famoso, porque nele Jesus ensinara as palavras do Pai-Nosso, a mais importante, para os cristãos, das orações.

[...] Pater noster, Qui es in caelis, sanctificetur nomem tuum. Adveniat regnum tuum. Fiat voluntas tua, sicut in caelo et in terra. Panen nostrum quotidianum da nobis hodie. Et dimitte nobis debita nostra, sicut et nos dimittimus debitoribus nostri. Et ne nos inducas in tentationem: sed libera nos a malo. Amen [...]

Os milagres foram para auxiliar os desafortunados. Jesus Cristo curou muitos doentes, incluso os cegos, por meio de massagem de suas mãos divinas misturadas com água e barro. Ele fez exorcismos, ressuscitou mortos como Lázaro, irmão de Marta, sua seguidora fiel. Alguns milagres tornaram-se contos perpétuos como na ocasião em que Ele caminhou sobre as águas do Mar da Galiléia, confirmando o poder da fé em Deus

\footnotetext{
Entre os relatos publicados sobre a vida de São José, raro na História da Literatura Mundial, encontra-se um livro de autoria de Leonardo Boff, da Editora Verus, intitulado "São José, a personificação do Pai". Nele, subtraímos ensinamentos do Autor que requer repasse como o de que José não era um pai alienado e distante; ao contrário, mostrava-se adorável para o filho, o guiava e o tranqüilizava constantemente com beijos. Depois de Maria, José era o mais respeitado, ouvido e valorizado por Deus. Aponta-se que numa nova corrente de estudiosos da crença religiosa, José, na sua espiritualidade, se comunicava e recebia mensagens do Senhor por meio de sonhos. uma espécie de mediunidade: a telepatia. E que provavelmente ele e Jesus teriam trabalhado não-só na carpintaria como, também,, nos campos, no cultivo de plantas e legumes e no pastoreio de cabras, ovelhas e de gado. São Mateus traça seu perfil como o de um homem de personalidade marcada pela justiça. Ressalto que o marido de Maria, pai de Jesus, não obteve posição merecida no âmbito da reflexão da Teologia. E lembro que milhões de pessoas, de lugares ou até de instituições levam o seu nome que, aliás, não aparecia em nenhuma lista de santos ocidentais até o ano 1000. O Qur'an, por exemplo, que é datado dos anos 600, dedica capitulo inteiro à Maria e nenhuma citação a José. Enfim, o pai da Sagrada Família teve a vida em um manto de discrição e o mesmo ocorreu com sua imagem na História do Cristianismo. Todavia, é adorado por milhões de admiradores. Ele é o pai do Messias, escolhido por Deus!
} 
ou de Jesus como Deus presente. Esses milagres são a realização das profecias do Velho Testamento: Deus existe. Deus é onipresente.

Todavia, o papel de Jesus não foi simplesmente o de um legislador moralista, sem outra autoridade que a Sua palavra. Ele veio cumprir as profecias anunciadas quando do seu advento. Sua autoridade decorria da natureza divina de Sua missão. Ele veio ensinar aos homens que a verdadeira vida não está na Terra, mas no Reino dos Céus; ensinar-lhes o caminho que os conduz até lá; os meios de se reconciliarem com Deus e os advertir sobre a marcha das coisas futuras, para o cumprimento dos destinos humanos. Não-obstante, Ele não disse tudo e sobre muitos pontos se limitou a lançar o germe de verdades que Ele mesmo declarou não poderem ser então compreendidas. Falou de tudo, mas em termos mais ou menos claros, de maneira que - para entendermos o sentido oculto de certas palavras - era preciso que novas idéias e novos conhecimentos viessem a nos dar a chave. E essas idéias não podiam surgir antes de certo grau de amadurecimento do Espírito humano. Com o passar dos tempos, a Ciência devia contribuir, poderosamente, para o aparecimento e o desenvolvimento dessas idéias. Em síntese, era preciso dar tempo à Ciência para que ela progredisse!

3. A última ceia. A paixão. Herodes. Crucificação/Ressurreição

3.1. A maioria dos cristãos é sabedora de que cada um dos quatro evangelhos narra os últimos dias de Jesus na cidade de Jerusalém. Nesses livros, se descreve a última ceia com seus discípulos como, também, a traição de Judas, ${ }^{4}$ o julgamento por Pôncio Pilatos, a crucificação e a deposição no sagrado sepulcro. Por meio dessa seqüência de fatos, os cristãos os traduzem pela palavra Paixão que significa sofrimento e relembram a Paixão todos os anos na Semana Santa.

Por ordem de Pôncio Pilatos, Jesus Cristo foi condenado à crucificação e a sentença recebida a contemplar aconteceu em uma sexta-feira, dia conhecido pelos cristãos como Sexta-Feira Santa. Antes do ato, o Filho de Deus foi forçado a carregar a própria cruz até a colina chamada Gólgota, localizada aos arredores de Jerusalém. Ele fora

A história do discípulo que traiu seu Mestre por trinta moedas de prata é uma das mais conhecidas do Cristianismo. Segundo o Evangelho de Judas, um manuscrito copta em idioma falado pelos antigos egípcios, escrito entre os séculos III e IV, o apóstolo pode ter sido condenado injustamente pela História. No texto, descoberto nos anos 70, no Egito, o personagem mais odiado do Cristianismo aparece como o discípulo mais próximo e querido de Jesus Cristo. Ele denuncia o Mestre às autoridades romanas a pedido do próprio Messias, num plano que seria essencial em sua missão de salvar a Humanidade e nos fazendo acreditar ser a mais difícil de ser cumprida em parâmetro às demais missões dos apóstolos. Na versão do Novo Testamento, Judas se enforca, arrependido e no texto apócrifo o enredo é totalmente diferente: ao compreender a importância de sua missão, Judas teria se retirado para meditar no deserto, aonde veio a morrer. 
crucificado ao lado de dois ladrões, sendo esse evento classificado na Religião cristã como ponto central, porque analisam que Ele morreu junto para absolvê-los dos seus pecados.

3.2. Cumpre salientar que Jesus Cristo reunido com seus discípulos, dentre eles Judas, pela última vez numa ceia de Pessach teve no encontro o aviso de que o momento de sua morte se aproximava. Ele tomou do pão, partindo-o e abençoando-o; em seguida, solicitou que o comessem, dizendo:

\section{"Este é o meu corpo"}

Jesus, então, disse aos discípulos que bebessem o vinho, dizendo:

"Este é o meu sangue"

Assim, surgiu o Ritual cristão da Eucaristia ou Sagrada Comunhão.

3.3. A dinastia de Herodes Antipas era composta de família real que governava setores da antiga Palestina durante o período do Império romano. Herodes, o Grande, governava à época do nascimento de Jesus, reinava a Galiléia no tempo de sua crucificação e interrogou Jesus a pedido de Pôncio Pilatos. Pilatos era governador da Província romana da Judéia ( 26 a 36 d.C.), controlava o sistema judiciário na região e as forças militares ali sediadas. Quando Cristo foi levado a julgamento diante de Pilatos, o governador condenou-o à morte a pedido das autoridades judaicas.

Neste contexto, a família de Herodes tornara-se famosa, porque sua mulher Herodíades e Salomé, a filha, reivindicaram a cabeça de João Batista, sendo prontamente atendidas. O marco chocante foi a apresentação do crânio do primo de Jesus, sobre uma bandeja de prata levada às duas mulheres durante uma das festas profanas apreciadas por elas, que não passavam de prostitutas de luxo daquela época.

Nos livros de Marcos, é narrada a história de um menino vestido de pijama que seguia assustado insistentemente Jesus, enquanto ele era levado pelos soldados romanos. Os soldados tentaram agarrá-lo, puxando o lençol (pijama) que o envolvia sem sucesso, porque ele escapuliu e fugiu. Por que Marcos nos oferece esse enredo cheio de curiosidade e detalhes? Com certeza, é um personagem importante! O fato é, segundo o texto, Jesus tinha um filho. Esse menino aparece novamente ao pé da cruz, único homem mencionado nos evangelhos, a acompanhar Maria Madalena e a mãe de Jesus, na crucificação. Somos conhecedores de que os evangelhos contam que os romanos puseram uma coroa de espinhos na cabeça de Cristo e acima dela escreveram "Rei dos Judeus" A mensagem oficial que os romanos queriam divulgar era a de que este seria o futuro de quem alegasse descender do Rei David; e trocando em linguagem popular, se Jesus tinha 
um filho, herdeiro varão ao trono de David, este filho necessitaria ser escondido, pelo temor de que ele logo pudesse também usar uma coroa de espinhos.

Segundo os autores Simcha Jacobovici e Charles Pellegrino em A tumba da família de Jesus, referendada no final deste trabalho, a questão é que os evangelhos nos convidam a especular a identidade secreta do Discípulo Amado e do garoto que corre nu pelas ruas de Jerusalém na noite em que Jesus foi detido. E o motivo mais plausível - para esconder a identidade de um menino no círculo mais íntimo de Jesus seria de que ele era seu filho. João registra que Jesus viu sua mãe com o Discípulo Amado ao pé da cruz. Ele então diz a ela: "Mulher, eis aí o teu filho!" Virando-se para o discípulo, diz: "Eis aí tua mãe" (João 19:26-27). Daí em diante, João nos conta, Maria dividiu o mesmo teto com o Discípulo Amado. E aqui fica claro que eles constituíram uma família e mais provavelmente, seriam avó e neto.

E também não seria possível, como alguns estudiosos sugeriram, de que Maria Madalena fosse sempre substituída nos evangelhos por Maria, mãe de Jesus, para ocultar seu papel na vida de Jesus. E se for este o caso, o incidente na cruz pode ser reinterpretado como as últimas palavras de um homem à sua esposa ("mulher"), antes de morrer e não à sua senhora mãe, pedindo-lhe que superasse seu sofrimento e protegesse o filho deles do perigo iminente.

Segundo a obra citada de Simcha e Charles:

juntos, os evangelhos, os textos não-canônicos, as tradições orais, os testes de DNA e a arqueologia parecem contar a mesma história. Havia um filho e ele encontrou seu lugar de descanso final ao lado dos pais, tio e avó numa tumba (tumba de Talpiot) de família na metade do caminho entre seu lar ancestral (Belém) e Jerusalém, onde eles esperavam estabelecer sua dinastia.

Depois de morto, Ele foi deposto no sagrado sepulcro de Jesus de Arimatéia, um de seus fiéis seguidores. Os Livros Sagrados contam que no domingo, depois da crucificação, algumas mulheres foram ao local e verificaram que estava vazio e, assim, souberam que Jesus ressuscitara de entre os mortos. A Ressurreição é o ponto crucial do milagre cristão, uma vez acreditam que Jesus Cristo está vivo e que logo retornará para reinar em paz.

3.4. Após a crucificação e ascensão, aproximadamente em 33 d.C. seus discípulos pregaram entre os judeus do Leste do Mediterrâneo e registraram sua fé em Escrituras, ajudando a difundir o Cristianismo. O mundo não lhe dá atenção! E no início do século XXI aproximadamente um-terço da população mundial - cerca de 2,8 bilhões de pessoas - são considerados seguidores daquele pregador judeu, o último numa linha de figuras religiosas carismáticas que foi executado pelas 
autoridades romanas, atendendo pedido de legisladores judaicos.

Ao digitar o Seu nome na Internet, obtém-se aproximadamente 100 milhões de respostas! Milhares de livros foram escritos sobre Jesus Cristo em parâmetro a qualquer outro personagem da História da Humanidade.

Dentre seus seguidores, os esforços do missionário Paulo, falecido em 65 d.C., fizeram a Religião avançar e consolidaram uma base segura no Império romano. Originalmente perseguidor dos cristãos, Saulo de Tarso converteu-se ao Cristianismo depois de ter uma visão de Jesus na estrada para Damasco. Mudou seu nome para Paulo e empreendeu série de jornadas missionárias ao redor do Mediterrâneo. Hoje, São Paulo, fundou igrejas na Ásia Menor, Síria, Chipre e Grécia, às quais retornou para colaborar em trabalhos messiânicos. Paulo escreveu famosa coleção de Epístolas ou Cartas que, atualmente, integram o Novo Testamento.

Com relação às mudanças de nomes, Jesus deu a seu discípulo Simão o nome de Pedro que significa "rocha" ou "pedra" Isso significava que ele deveria ser o fundamento da Igreja primitiva. Após a ascensão de Jesus, São Pedro (atualmente) se tornou o líder dos cristãos como, também, pregou em muitas partes do Mediterrâneo e fundou a Igreja cristã, em Roma. O seu túmulo está localizado em uma das criptas do Vaticano. Tal como o Império romano, o Cristianismo gerou duas correntes: a ocidental, baseada em Roma, e a oriental, baseada em Constantinopla (hoje Istambul), sendo que dessas duas correntes originaram a moderna Igreja católica e ortodoxa. Muito tempo depois, com o movimento conhecido como Reforma, ${ }^{5}$ emergiu o protestantismo, terceira corrente do Cristianismo. O Espiritismo, mescla de Religião e Filosofia, tem seu respaldo de fé e crença nos Ensinamentos de Jesus Cristo.

\section{Tesouros dos primeiros cristãos}

No Egito, em 1945, portanto há 65 anos, um pastor encontrou em uma gruta localizada próxima à sua aldeia um volumoso jarro de cerâmica. Ele levava suas ovelhas

\footnotetext{
No início do século XVI, surgiram críticas à corrupção da Igreja católica e a algumas de suas práticas sacerdotais e assim, reformadores como o francês João Calvino e o alemão Martinho Lutero, instavam os cristãos a retornarem aos ensinamentos da Bíblia cristã ao pé da letra, mesmo que isso significasse ignorar as tradições da Igreja. E Lutero, qualificado pelos historiadores como o mais importante dentre os reformadores, reprovava a prática da Igreja de vender indulgências que prometiam o perdão de Deus aos pecados. Ele escreveu 95 teses ou argumentos protestando contra essa prática e afixou o documento na porta da Igreja de Wittenberg. Lutero traduziu as Escrituras para o alemão no intuito de que as pessoas comuns pudessem entendê-las. E o Movimento Reformista iniciado por ele se espalhou pela Europa. Os adeptos das igrejas protestantes decorrentes da Reforma acreditavam que as palavras da Bíblia tinham mais autoridade do que as tradições cristãs. E igrejas protestantes vieram a dominar o Norte da Europa, enfatizando a GrãBretanha, a Alemanha e a Escandinávia.
} 
para pastar. Ao abrir o jarro, o pastor encontrou dezenas de folhas em blocos escritos em idioma que ele não conhecia. Levando o bloco de folhas para casa, algumas delas infelizmente - e felizmente para o pastor - serviram de alimento ao forno a lenha, na tarefa de cozinhar. $\mathrm{O}$ resto do bloco veio a cair em mãos de um vizinho religioso da aldeia. Esses blocos resgatados, por sua vez, foram parar em mercado de antiguidades e arrebatados por um funcionário do Governo egípcio.

Mais tarde, descobriu-se que a "lenha" era um tesouro de valor incomensurável. Tratava-se da Coleção Nag Hammadi composta de treze livros com mais de 1.600 anos e repleta de histórias que a Igreja - durante todos aqueles anos tentou esconder a verdade da História do Cristianismo. Não conseguiu!

$\mathrm{O}$ achado se tornou o mais importante acervo de Evangelhos Apócrifos: literatura que tem auxiliado a elucidar todos os mistérios da Religião cristã. Os escritos de Nag Hammadi foram realizados entre os séculos I e III; seus autores pertenceram às primeiras comunidades cristãs. Nesse acervo, é possível conhecer os Livros que ficaram de fora ou mesmo banidos do Novo Testamento, tais como os Evangelhos de Tiago e de Tomé, totalmente destoados do que aparece na Bíblia. O acervo desses Evangelhos, segundo pesquisadores, cientistas e historiadores, nos fez conhecer que Jesus tem um lado sensivelmente humano e Madalena, além de mulher sensível e inteligente, era a líder do grupo cristão.

A premissa maior dos detalhes da Coleção é a de que Deus é um Princípio Masculino e Feminino; portanto, relatos diferenciados dada a polêmica é cristalino o motivo de terem sido banidos da coletânea bíblica. Ressalta-se que naqueles anos não havia um cânone que é o nome referendado ao conjunto oficial de livros que compõem a Bíblia cristã. Mas muitos textos - cada um deles escrito por membros de diferentes seitas existentes que registravam seus valores e crenças como a origem do Universo e sobre Deus e o Messias - são divergentes em seu conteúdo. Por exemplo, os docetas negavam a realidade material de Jesus Cristo, porque consideravam que Ele possuia um corpo etéreo e que, por isso, não nasceu nem foi morto na cruz e muito menos ressuscitou. Os ebionitas defendiam que o Messias havia nascido de maneira natural e somente depois de batizado foi que Deus decidiu adotá-lo. E os ofitas acreditavam que Caim foi o representante espiritual mais elevado e que a morte de Jesus Cristo foi crime do Universo, mas acontecimento necessário para a salvação da Humanidade.

Cumpre salientar que de todos os grupos (assim definidos porque são compostos por famílias e/ou amigos que tinham afinidade tanto espiritual quanto ideológica), o que mais influenciou o Cristianismo primitivo foi o dos gnósticos que adoravam uma vida ascética, negavam a matéria e acreditavam que o conhecimento era o único caminho em direção à salvação. 
Desta lista, constam os Evangelhos de Tiago, de Tomé, de Filipe, do Salvador, da Verdade, e de Maria Madalena. Também se incluem obras significativas ligadas às tradições alternativas: Apócrifo de João, Diálogo do Salvador e Apócrifo de Tiago.

Como assinalado acima, outros grupos defenderam que Deus possuía Princípio Masculino e Feminino. De fato, as mulheres desses grupos atuavam como mestras, líderes e profetisas: idéia totalmente revolucionária para a Igreja até os dias atuais!

Em 2003, Bart D. Ehrman, da Universidade da Carolina do Norte, publicou a obra intitulada Lost Christianities: The battles for Scripture and faiths that we never knew [Cristianismos perdidos: a batalha pelas Escrituras e pela fé que nunca conhecemos], pela Oxford University Press. E o resumo do livro citado, na parte interna da capa, diz o seguinte:

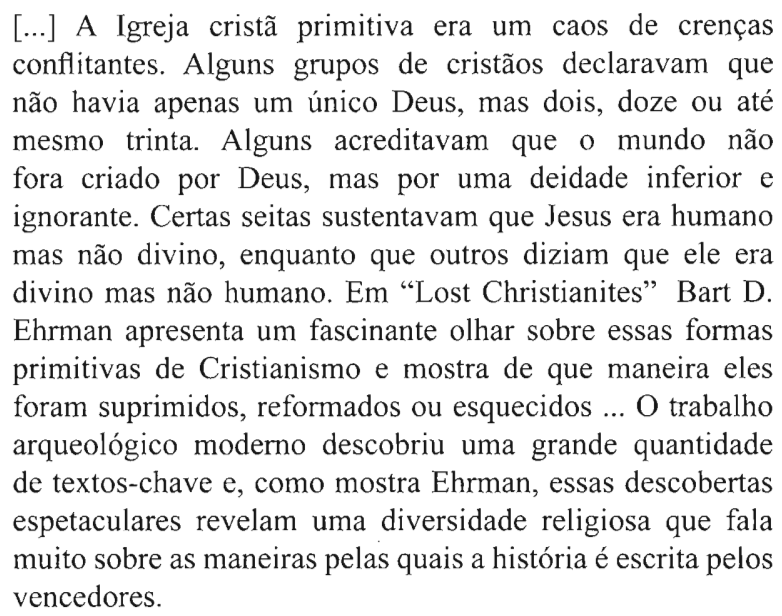

No mesmo ano, Elaine Pagels, da Universidade Princepton, lançou obra que prosseguiu neste tema intitulada Beyond Belief: The secret Golpel of Thomas, publicada no País com o título Além de toda crença: o Evangelho desconhecido de Tomé, pela Editora Objetiva. E esse novo livro destaca o valor daquilo que outros têm chamado de "o Quinto Evangelho" uma obra do século II de origens obscuras, mas que afirma refletir 114 dizeres de Jesus Cristo. Esse Evangelho foi o texto que mais recebeu a atenção desde os escritos de Nag Hammadi. Na capa deste livro, há importante afirmação sobre a origem do Cristianismo ortodoxo. A ortodoxia é intitulada de emergente em seus primeiros anos, porque não estava cristalino que ela inteirava a fé cristã. E assim, a obra de Elaine Pagels defende que essa fé emergente se saiu melhor que seus oponentes.

Desse modo, o Cristianismo ortodoxo seria na verdade o produto de Irineu, um Pai da Igreja posterior, do século II, e daqueles que o seguiam. Com o passar dos tempos, milhões de comentários acerca dos escritos de Nag Hammadi não estavam restritos 
aos acadêmicos; dentre eles, as obras de Dan Brown, enfatizando O Código Da Vinci, Anjos e Demônios que aludiram a estas teorias ao editar os históricos de seu romance. E o Autor afirmou em entrevistas internacionais que o esboço de O Código Da Vinci refletia a nova visão dos acadêmicos sobre a História das Religiões. Brown argumentou que as raízes históricas de seu romance precisavam de uma discussão ampla e pública. O Autor estava certo, porque é preciso olhar mais de perto para todas as suas teorias, inclusive a da segunda obra, Anjos e Demônios, que narra a operação ressuscitada dos iluminati (sociedade secreta da Baviera, fundada em maio de 1776, Era do Iluminismo; muitos teóricos acreditam que os iluminati são o cérebro por trás dos acontecimentos que levarão ao estabelecimento de uma Nova Ordem Mundial e que terá como objetivo maior unir o mundo em única regência que se baseia em modelo político, onde todos são iguais).

Por fim, cabe salientar que a Igreja ortodoxa é mais forte na Grécia, Turquia e no Leste da Europa, sobretudo na Rússia e na Bulgária. O Cristianismo ortodoxo ou oriental diverge do catolicismo em vários aspectos. Por exemplo, há diferenças quanto à doutrina da Santíssima Trindade e ao idioma do culto. Os ortodoxos se utilizam do idioma grego e os ocidentais do latim. E a Igreja ortodoxa também rejeita a autoridade do Papa, considerando que todos os bispos são iguais.

Por último, cita-se o Cristianismo apostólico, baseado nas narrativas dos primeiros discípulos de Jesus. Esses discípulos contavam que o Messias havia sido crucificado para salvar a Humanidade e que cabia aos seus seguidores a missão de disseminar Sua Mensagem através dos quatro cantos do mundo. Essa tradição começou a ser registrada por volta dos anos 30 e 40 do século I e em livros como os Evangelhos de Marcos, Mateus, Lucano (apelido, Lucas) e João lidos por muitos membros desses grupos que consideravam os relatos mais antigos com perfil preciso e correto da vida de Cristo. Eles foram organizados no século II, quando bispos da época decidiram compor as Escrituras. Tinham de traduzir os textos para vários idiomas e divulgá-los entre vários povos. Também tinham de aparar as diferenças e chegar a um consenso de versão oficial.

\section{A versão oficial}

E nesse redemoinho de vaidades e paixões, as Igrejas maiores e mais influentes tentaram impor seus textos, acarretando divergências, uma vez as menores não acatarem grande parte das decisões escolhidas pelas primeiras. Aconteceram debates e acusações mútuas de heresia entre as partes. Essa batalha atingiu o século III, quando tudo indicava que o Cristianismo apostólico iria prevalecer sobre os demais cristianismos. Nessa época, os quatro Evangelhos eram populares, sendo elogiados desde o século II pelos pensadores da Igreja, mas até então não eram livros oficiais.

Quando o imperador de Roma, Constantino, entrou em cena e interveio no impasse o Império romano estava em crise. O imperador necessitava de uma bandeira 
para justificar a expansão romana e, além disso, tinha de tentar convencer outros povos a aceitarem o seu domínio. Na verdade, uma aliança: de um lado, o imperador romano e, de outro, os cristãos que desejavam divulgar a Mensagem de Cristo mundo afora.

Os cristãos deixaram de ser perseguidos em 313 e apenas 12 anos depois seus bispos foram convocados para o Concílio de Nicéia que, no transcorrer da História da Religião, foi o primeiro passo para a criação do Novo Testamento. Na reunião, os Evangelhos de Marcos, Lucano (apelido, Lucas), Mateus e João foram os escolhidos para narrar a biografia de Jesus Cristo e por motivo bem simples: expressavam a visão dominante na Igreja, quando todos os demais foram considerados apócrifos, falsos e perigosos para a edição do Novo Livro.

Para finalizar, acentua-se que houve perseguição a todos que ousassem discordar da recém-formulada Escrituras Sagradas.

Os gnósticos, docetas, ebionitas e ofitas foram acusados de heresia. Os que insistiam em desrespeitar o cânon eram punidos com a excomunhão ou até com a morte. Centenas de livros, uma vez não haver cômputo correto, foram queimados ou destruídos. Foi nessa época que alguém decidiu esconder os treze pacotes com escritos na gruta da aldeia Nag Hammadi, no Alto do Egito. Arqueólogos e pesquisadores acreditam que talvez um cristão perseguido ou um monge do Mosteiro de São Pacômio, que ficava perto da gruta, os tenha guardado. Seja lá quem foi, a Humanidade agradece, porque os apócrifos são documentos essenciais para compreensão e História do Cristianismo.

\section{O catolicismo. O Papa}

Recapitulando, após anos e anos de perseguição, verifica-se que os cristãos tiveram a sorte de suas vidas em Roma darem uma guinada no século IV d.C. com a decisão de o próprio imperador Constantino I se converter ao Cristianismo, sendo que em 313 ele ordenou o fim das perseguições e o reconhecimento deles aos direitos civis em todo o Império. Em 320, o Cristianismo tornou-se a Religião oficial do Império romano. E assim, a Igreja católica cresceu, a partir da primitiva comunidade cristã de Roma que, por sua vez, passou a considerar São Pedro o primeiro bispo da cidade como, também, o primeiro Papa; depois da queda de Roma, a Igreja sobreviveu na Europa Ocidental e se tornou a força dominante do Cristianismo, nessa região. Hoje, o catolicismo é aceito e praticado em todo o mundo.

O líder da Igreja católica é o Papa e os cristãos acreditam que ele é o sucessor direto de São Pedro, sendo, portanto, o representante ou o vigário de Jesus Cristo.

A natureza do poder de governo do Papa tem as seguintes características:

* ordinária, suprema, plena, imediata, inclui o primado de honra sobre toda a Igreja; 
* Roma, enquanto a primeira sede de governo de Pedro: poder legislativo, isto é, fazer leis universais para toda a Igreja ou particulares e dispensar das mesmas;

* poder executivo ou administrativo que é a reserva de penas eclesiásticas;

* disciplina da liturgia e dos sacramentos;

* direção suprema dos institutos de vida consagrada;

* controle geral sobre os bens temporais das Igrejas particulares ou locais, as dioceses;

* poder judiciário que é o de avocar a si qualquer causa;

* juizo dos chefes de Estado, dos cardeais, patriarcas, legados e núncios apostólicos e bispos em causas criminais, direito de não ser julgada por ninguém;

* primado de magistério, a infalibilidade ex-cátedra que abrangem só ensinamentos em questões de fé e de moral;

* condenar doutrinas errôneas ou livros considerados perigosos; proclamação e supressão dos institutos de viça consagrada.

A Igreja ocidental é baseada em Roma e a oriental em Constantinopla (hoje, Istambul). As duas igrejas divergiram sobre certos aspectos com relação à fé e, em 1054, houve uma ruptura que é conhecida como Grande Cisma (separação). Nunca foi fácil aos historiadores e pesquisadores determinar a formação exata das comunidades cristãs. Todavia, os discípulos de Cristo acreditavam que Deus havia ressuscitado Jesus dos mortos como, também, que o Espírito de Deus ou de Jesus estava com eles.

No Evangelho de João, Jesus ressuscitado envia Seu Espírito Santo diretamente aos discípulos por meio de sopro sobre eles. E uma história diferente aparece no Livro dos Atos em episódio da Igreja inicial escrita pelo mesmo evangelista Lucano (apelido, Lucas), provavelmente na década de 80 do século I. No Livro dos Atos há a afirmação de que Jesus Cristo ressuscitado deixou seus discípulos depois de 40 dias e eles receberam o Espírito Santo de Deus logo depois, durante o Festival Judaico de Pentecostes, o qual thes deu tanto força espiritual quanto habilidade milagrosa de se comunicar em vários idiomas. E por meio dessa força, Pedro falou às multidões, que havia se reunido em Jerusalém, para celebrar o Pentecostes.

No Livro de Atos 2:22-24, 36, o fato:

[...] Israelitas: ouvi estas palavras de Jesus de Nazaré, homem de quem Deus tem dado testemunho diante de vós com milagres, prodígios e sinais que Deus por Ele realizou no reino de vós; como vós mesmos o sabeis, depois de ter sido entregue, segundo determinado desígnio e presciência de Deus, vós o matastes, crucificando-o por mãos de ímpios. Mas Deus o ressuscitou, rompendo os grilhões da morte, porque não era possível que ela o retivesse em seu poder. 
Que toda a casa de Israel saiba, portanto, com a maior certeza de que este Jesus, que vós crucificastes, Deus o constituiu Senhor e Cristo.

O Livro dos Atos nos relata que 3 mil pessoas se reuniram aos discípulos como saldo positivo do pronunciamento de Pedro e que, nos dias seguintes, constituíram uma surpreendente comunidade:

[...] De todos eles se apoderou o temor, pois pelos apóstolos foram feitos também muitos prodígios e milagres em Jerusalém e o temor estava em todos os corações. Todos os fiéis viviam unidos e tinham tudo em comum. Vendiam as suas propriedades e os seus bens e dividiam-nos por todos, segundo a necessidade de cada um. Unidos de coração freqüentavam todos os dias o Templo. Partiam o pão nas casas e tomavam a comida com alegria e singeleza de coração, louvando a Deus e cativando a simpatia de todo o povo. E o Senhor a cada dia lhe ajuntava outros que estavam a caminho da salvação.

Premissa final, para que não haja muita prolongação: quem conduziu essas cerimônias?

Não se tem certeza alguma; o certo é de que havia lideranças cristãs desde os primeiros tempos; mas, também, é incerto em que extensão correspondia ao que, atualmente, se intitula de sacerdotes. E também é incerto o perfil de uniformidade dessas lideranças mediante as diferentes igrejas da antiga época.

Em uma hierarquia encontram-se os apóstolos; apóstolo significa alguém enviado. Sendo assim, eles eram as pessoas enviadas pelo Cristo: os líderes originais dos cristãos. Insere-se Paulo no topo, mas era Pedro, de longe, o mais importante de todos eles, além de o amigo mais próximo d'Ele. Embora no Livro de João existe um "discípulo amado", o que estudiosos chegam à conclusão de que esse ou essa seria a carismática, humilde e alegre, além de a mais intelectualizada, a Senhora Maria Madalena.

\section{Além do Império}

Afé cristã se difundiu além dos limites do Império romano e Edessa (hoje Urfa) foi um dos principais centros do Cristianismo, enfatizando os primeiros séculos. Edessa era a capital de um pequeno Reino chamado Osrhoene, ao Norte da Síria, independente desde o século II a.C. e era governado por sua dinastia de Reis descendentes de assírios, que séculos antes tinham fundado o Reino. E em 216 d.C. Osrhoene fora incorporado ao Império romano, quando uma curiosa lenda sobre a chegada do Cristianismo acontece.

O Rei Abgar V, comandante deste Reino referido, estava gravemente doente e ele havia ouvido falar de Jesus Cristo que, nesta época, fazia curas e milagres na Galiléia. O Rei pediu, por intermédio de seus missionários, que o Messias fosse até a sua cidade. 
Jesus recebeu o recado e escreveu educada resposta ao Rei Abgar, explicando que não poderia ir até Edessa, uma vez ter série de trabalhos a realizar em Jerusalém. Todavia, curou o Rei à distância e prometeu enviar-lhe discípulos para levar o Cristianismo à Edessa. A promessa foi cumprida e em Seu Nome o apóstolo Addai (conhecido por Tadeu, um dos doze apóstolos) chegou à cidade, evangelizando-a.

Dada a riqueza mercante de grande importância - uma vez a grande estrada para o Oriente pela qual vinham a seda e objetos de ouro e prata da distante China Edessa ainda tinha a vantagem de ser o elo da principal porta para o Oriente. E assim, se tornou importante parada para a Ásia e ali o Cristianismo garantiu que a Religião se espalhasse mais ainda; pelo menos, para a Pérsia que, nesta época, estava sob o domínio dos parses, influenciando-os acentuadamente. Os parses tinham vindo do Leste do Mar Cáspio e ali a principal Religião era o Zoroastrismo - fundada aproximadamente por volta de 1200 a.C. . cujo mentor era Zoroastro, também conhecido como Zaratustra, um homem estranho, mas incrivelmente sábio. Ninguém sabe ao certo onde nasceu e viveu Zaratustra; provavelmente na mesma época do Rei Herodes.

Pesquisas apontam, sem precisão, que ele viveu no atual Irã ou talvez Afeganistão. Sua Religião era dualista - o Bem e o Mal -, sendo que no futuro, o Bem triunfaria. $\mathrm{O}$ Zoroastrismo parece ter tido uma das doutrinas associadas às religiões monoteístas como a vida após a morte e era a Religião dominante na Pérsia; todavia, o Judaísmo também era elemento importante e, de fato, no tempo de Jesus havia mais judeus na Pérsia do que em qualquer outro lugar e muitos tinham permanecido ali após o exílio babilônico quando, no século VI a.C., os judeus foram escravizados. Mais ainda, poderiam ser descendentes das dez tribos perdidas da Palestina que, por sua vez, foram conquistadas e dispersadas pelos antigos assírios.

Nesse redemoinho de busca da verdade, o fato é que os judeus estavam vivendo muito bem ali por meio do comércio da seda com a China, que passava pela Pérsia. E é provável que o Cristianismo tenha vindo primeiro, fora dos limites do Império romano, para a Pérsia por intermédio dessas comunidades judaicas que, em sua maioria, falava o aramaico. E há outra corrente de pensadores a partir do século III: a de que o apóstolo Tomé trouxera o Cristianismo aos parses. Finalizando, qualquer forma que tenha sido de como o Cristianismo lá chegou, no fim do século II, a Religião cristã estava bem estabelecida na Pérsia.

A Era dos Apóstolos terminou por volta do final do I século d.C. A Era que inicia no século II e se estende aos séculos V e VI é conhecida como a Era dos Pais da Igreja católica, uma vez serem os primeiros a herdar uma Religião estabelecida e que tinham uma grande quantidade de trabalhos a realizar para que ela fosse compreendida e interpretada. E, nesse período, o Cristianismo assumiu a forma que atualmente conhecemos 
com doutrinas devidamente estruturadas, liturgias e hierarquias. Nesse iter desenvolvido, a corrida abrange os séculos I e III, quando o Cristianismo era até então considerado ilegal.

O Cristianismo evoluiu por meio do protetorado do forte e seguro Império romano, um país à parte, sob controle romano. Espalhou-se e floresceu, encontrando sua própria identidade dentro do universo romano. E era o que se queria a esse mundo.

\section{As Cruzadas}

$\mathrm{Na}$ Idade Média, os fiéis que rejeitavam algumas doutrinas da Igreja e que, todavia, se consideravam cristãos eram classificados como hereges. E naquela época, a Igreja católica criou a Inquisição, organismo cuja função era investigar e combater as heresias.

Dentre as crenças, a cruz é o símbolo universal do Cristianismo, lembra a morte de Jesus Cristo por meio da crucificação que é representado por um crucifixo com Ele pregado nela (o termo é forte, porém Jesus foi preso aos pregos). A cruz vazia era o símbolo durante toda a Idade Média de campanhas militares em nome do Cristianismo, chamadas Cruzadas. Essas campanhas militares eram tentativas de os cristãos ocuparem Jerusalém e garantir a segurança aos peregrinos que queriam visitar a cidade sagrada. Eles degeneraram uma série de guerras entre cristãos e muçulmanos, as quais não trouxeram benefícios a nenhuma das partes.

Era cristalino que as relações gradativamente estavam tensas entre cristãos bizantinos, mas esta tensão não era nada quando comparada às relações com os muçulmanos e nisso católicos e bizantinos estavam unidos. As tensões e as discrepâncias de fé e sentimentos envolviam os lugares sagrados associados a Jesus Cristo; dentre eles, e especialmente, a Igreja do Santo Sepulcro, onde se acredita ter sido o local do Seu túmulo.

Em 1009, o califa fatímida do Cairo Al-Hakim, que na época controlava Jerusalém ordenou e comandou a destruição desses lugares sagrados que foram restaurados pelos cristãos, maltratados até 1070. E nesse ano, os turcos seljúcidas conquistaram Jerusalém aos fatímidas; tentaram destruir os lugares sagrados e acentuaram os maltratos aos cristãos. A resposta cristã veio em 1095, quando o Papa Urbano II declarou que o domínio muçulmano no Oriente Médio, em geral, e nos lugares sagrados tinham de terminar. O Concílio de Clermont ratificou seu decreto e o povo, respeitosamente, respondeu. Uma série de poderosos exércitos, em 1096, fluiu em direção ao Oriente.

Em 1098, Edessa e Antióquia caíram para os cruzados e em 1099 foi a vez da própria Jerusalém que ficou sob o Governo cristão de Godofredo de Bulhão. Um sucesso para a Primeira Cruzada. Edessa, todavia, foi tomada pelos muçulmanos em 1144.

A Segunda Cruzada foi enviada pelo Papa Eugênio III e seu mentor foi Bernardo de Claraval. A cruzada partiu diretamente para a Terra Santa, onde sitiaram primeiro a cidade de Damasco; todavia, não conseguiram capturá-la, derrotando Claraval. 
O pior ainda viria com o poderoso general curdo Salah Al-Din que apareceu no Egito onde rechaçou as forças enviadas do Estado Cruzado de Jerusalém. Em pouco tempo, Salah Al-Din tornar-se-ia uma lenda como Saladino, o maior comandante muçulmano de sua época e aos cristãos o "bom infiel" uma vez famoso por sua misericórdia ao defender seus inimigos. Há uma lenda de que ele fora sagrado cavaleiro pelo Rei Ricardo I, da Inglaterra, que participara da Segunda Cruzada. Mas isso não evitou a Terceira Cruzada lançada pelo Papa Gregório VIII, em 1189, para retomar Jerusalém.

A Terceira Cruzada em parâmetro com as duas primeiras - constituídas quase que exclusivamente pelo povo - tem como mérito a participação dos Reis. O imperador do Sagrado Império romano, Frederico I, o Barba-Ruiva, acompanhou a cruzada, porém se afogou no caminho; o Rei Felipe II, da França, e o Rei Ricardo I, o Coração-de-Leão, da Inglaterra, tiveram presença em toda a cruzada, mas eles e seus cavaleiros não conseguiram retomar Jerusalém, tampouco com a robusta participação do Rei Alfredo, o Grande, que teve a companhia do guerreiro Angus MacLachlan.

Com o pouco sucesso, encontrou sua maior depressão na Quarta Cruzada, ordenada pelo Papa Inocêncio III, em 1198. A Quarta Cruzada sequer alcançou o Oriente Médio muçulmano, mas atacaram Constantinopla, capturando-a e massacrando toda a população e lá instalaram um Rei católico. O fato de a capital do Império bizantino e, portanto cristã, não os intimidou, embora o governo católico da cidade tenha tido uma gestão de 50 anos e o Governo bizantino, tendo sido mais tarde restabelecido; o incidente foi o pior entre as relações da Igreja católica e ortodoxa.

Cumpre salientar que ainda o fato tem sabor amargo entre os ortodoxos de hoje, além de a excomunhão mútua, de 1054, ter trazido enorme obstáculo, durante séculos, para tentativas de reunião e união. Além de uma particular cruzada lançada pelo imperador Frederico II, em 1228, que capturou Jerusalém e a manteve por mais de 50 anos não houve mais nenhum sucesso cristão no Oriente Médio. Pelo contrário, os mamelucos, que haviam substituído a Dinastia Omíada, lentamente retomaram toda a região perdida, culminando em 1281 em Acre, o último posto avançado das cruzadas.

E assim, o Ultramar cristão, como era conhecida a região, durou pouco mais que um século e meio, porém teve grandes conseqüências para a natureza da civilização cristã, em Roma.

\section{Os Templários}

A palavra hebraica, original, que designava o livro da Bíblia hoje conhecido como Gênesis é Bereshith, cujo significado é No Princípio. Nele, encontradas narrativas oriundas de várias fontes muito antigas que, pelas tradições narradas, antecedem registros escritos em milhares de anos. E o que emerge claramente do seu estudo e também desses registros antigos, como o Bereshith, é que havia guardiões, guias protetores e líderes fortes 
e bem informados, os quais pareciam donos de um conhecimento incrível e a fontes de poder que, em geral, não se tinha absolutamente nenhum acesso.

São os templários que pertenceram à Ordem de Guardiões e Protetores e que eram homens com o único propósito de proteger cristãos em geral; todavia, os segredos sobre a origem antiga da Ordem podem ter-se perdido, mas não seus propósitos. Nesse emaranhado de mistérios, o primeiro é o enigma de sua verdadeira origem e propósitos; o segundo, a natureza exata dos segredos arcanos e misteriosos que eles protegiam há tanto tempo e que até os dias de hoje continuam sendo guardados; o terceiro, o seu sistema de codificação e decodificação, porque eles eram semiólogos e criptólogos experientes e o quarto mistério é o enigma sobre o que aconteceu a todos eles, depois do ataque injustificável, em 1307, por parte do ambicioso Rei Filipe IV, da França, conhecido como o Belo, justamente pela sua aparência de homem alto, forte e musculoso; olhos cintilantes e cabelos ondulados, causando certo frisson entre as mulheres de sua época.

Em 1118, nove cavaleiros chegaram à Jerusalém e assumiram para si o papel de proteger ostensivamente os peregrinos dos ladrões, quando o Rei Balduíno II os acolheu alojando-os no Monte do Templo, local conhecido, na época, por Estábulo de Salomão. Essa informação é de vital importância, porque era exatamente o que eles faziam, tendo nesta proteção a participação do influente Bernardo de Clairvaux, ou Claraval, período em que a Ordem Templária fora reconhecida pelo Vaticano e conhecida, formalmente, como Ordem dos Pobres Cavaleiros de Cristo e do Templo de Salomão. Eles tinham como missão obediência exclusiva ao Papa e não tinham obrigação de pagar impostos a nenhum Governo secular ou mesmo Igreja oficial, o que era na época enorme vantagem para a Ordem.

Existem teorias que tentam dar explicações sobre o carisma e as qualidades sobre-humanas de alguns desses antigos guardiões da Humanidade, inclusive a idéia de que eram extraterrestres ou, ainda, do cruzamento de extraterrestres com humanos. E neste contexto, o Bereshith, atual Gênesis 6:2-4, contempla a questão de maneira incontestável:

\begin{abstract}
[...] Os filhos de Deus viram que as filhas dos homens eram extremamente belas. E escolheram esposas entre elas ... Naquele tempo viviam gigantes na Terra ... quando os filhos de Deus se uniram às filhas dos homens e elas geravam filhos: estes eram os heróis, tão afamados nos tempos antigos.
\end{abstract}

Dentre todos os registros, o mais famoso é o da Epopéia de Gilgamesh. Essa narrativa contém mais segredos estranhos que podem se relacionar com as origens desta ordem secreta de guardiões, conhecida no século XII como Ordem Templária, os templários. Especialistas calculam que a história de Gilgamesh tenha mais de seis milênios e é possível que seja ainda mais antiga.

A narrativa conta a história do Rei sumério semidivino Gilgamesh de Uruk; de sua união amistosa com o poderoso sábio Enkidu; sua vitória conjunta sobre Humbaba, 
o terrível guardião de florestas; a morte de Enkidu e a dor inconsolável de Gilgamesh, quando da morte de seu amigo, cuja união era semelhante a Alexandre III, o Grande, da Macedônia com seu eterno parceiro e amante, Ephestrium. Por toda a obra, Gilgamesh é classificado como defensor e protetor de seu povo sumério, além de ter inúmeros poderes sobre-humanos, assim como sabedoria incomum; sua palavra era lei em todo o Império sumeriano.

Em sentido geral, o Rei sumeriano pode ser entendido como um guardião templário típico e protetor de algo muito poderoso e profundamente secreto. Em um cômputo geral, citam-se como primeiros templários, as figuras de deus-pai Odin, Júpiter e Zeus, conhecidos por diferentes nomes em culturas e épocas diversas, bem como os deuses guerreiros Thor e Marte; acrescentem-se outro deus nórdico como Ull, também chamado Ulir ou Oller, Nimrod, Gilgamesh e Enkidu, Enlil da Babilônia, terminando com Hermes Trismegisto, Hermes ou o Três Vezes Abençoado, conhecido como Thor. E o poderoso, por último, Melquisedeques, além de um escriba poderoso do Egito. São nove primeiros, no total.

E quem eram esses nove cavaleiros templários e qual o motivo de eles estarem no século XII, em Jerusalém? Uma pergunta cabível, quando se chega à conclusão de que estiveram a serviço de Hugo de Champagne que tinha parentesco com a família dos Saint Clairs de Rosslyn, vindo ao encontro da importância da Capela Rosslyn, na Escócia.

Da lista, o primeiro a chegar em Jerusalém foi Hugo de Payns, seguido por André de Montbard, Godefrois de Saint Omer, Payen de Montdidier, Achambaud de Saint Amand, Geoffroi Bisol, Rosal e Godfroi. E chega-se a Abraão, que veio de Ur dos caldeus e era filho de Taré, descendente de Noé por intermédio de Sem, seu filho. Abraão se mudou de Ur para Harã, famoso centro comercial no Vale do Rio Eufrates. Taré, seu pai, havia morrido nesta cidade e segundo relatos bíblicos ele sentiu um chamado divino para se mudar para uma nova terra, onde Deus prometeu que ele se tornaria o Pai das Nações e seria uma bênção universal.

No Hinduísmo há um relato interessante em termos de teoria etimológica sobre o nome de Abraão, enfocando a sílaba Ram, isolando o prefixo ab/ap, que é uma palavra do idioma caxemira, cujo significado é pai. Na Religião hinduísta, Ram é conhecido como Lorde Ram que, por sua vez, é a reencarnação ou avatar de Vishnu. Breve lembrança no Hinduísmo é a de que Brahma é nascido de uma flor de lotus, a qual floresceu no umbigo de Vishnu. E alguns historiadores o identificam com o patriarca caldeu Abraão, porque Lorde Ram é considerado a personificação de tudo o que é bom, ético, virtuoso; nunca mentia, não adoecia e nem envelhecia. Também é descrito como um guerreiro invencível e o Espírito mais corajoso que passou sobre a Terra. ${ }^{6}$

6 Estes menestréis medievais estavam envolvidos em um culto secreto geralmente referido pelos historiadores 
Nomes como o de Alexandre III da Macedônia, conhecido como Alexandre, o Grande, que além de ser considerado o Espírito mais belo que passou pelo nosso planeta, foi excelente estadista, filósofo, teólogo e metafísico; o Rei Minos, de Creta, que teria recebido instruções divinas diretamente de Zeus; Merovech, o Duas Vezes Nascido, conhecido como Meroveu ou Mérovée - o Rei que deu seu nome à Dinastia Merovíngia são considerados os primeiros nomes templários pelos pesquisadores da História da Humanidade. A origem dos merovíngios remonta à tribo dos chamados sicambrianos, os quais faziam parte de uma comunidade conhecida como francos. Eles foram força poderosa nas questões francesas e alemãs nos séculos V, VI e VII.

O imperador hebreu Salomão que ascendeu ao trono de Jerusalém em 922 a.C. consolidou o Império deixado por seu pai David e reinou com prosperidade em virtude de série de alianças criadas meticulosamente por ele, inclusive as de casamentos reais. Quando Salomão morreu, Reboão seu filho não conseguiu manter a paz no Reino herdado. As dez tribos de Israel do Norte se rebelaram sob a liderança de Jeroboão, filho de Nebate, e restou a Reboão apenas o pequeno Reino da Judéia. O Império Salomão era quatro vezes maior que a Israel do século XXI. Ele se estendia desde Tifsa, no Rio Eufrates, por todo o Norte até o Porto de Helát, no Mar Vermelho, alcançando o Golfo de Acaba, ao Sul. O Egito e o deserto arábico ficavam na parte Sul e os territórios hititas ficavam ao Norte do Império de Salomão. Ele controlava uma fronteira litorânea significativa ao longo da Costa Leste do Mediterrâneo, e sua frota de navios mercantes viajava por todas as terras ocidentais do Mediterrâneo e a todos os portos mercantis ao Sul que eram acessíveis pelo Mar Vermelho.

E foi no que antes tinham sido terras pacíficas e prósperas do Rei Salomão que os templários e seus companheiros cruzados confrontaram as eventualidades do sucesso e do fracasso por meio de vitórias difíceis e derrotas amargas. Batalha após

e pesquisadores como culto à Madona Negra. Psicólogos junguianos místicos vêem a Madona Negra sinônimo da Mãe Terra ou da antiga divindade matriarcal. Quase todos os antigos panteões contêm deusas poderosas e em certo sentido a teologia da Madona Negra perpetua os seus mitos. Ela é Ceres, a deusa romana da agricultura, Ísis, Aremis, Vênus, Afrodite, Diana dos Efésios ou Gaia. Essencialmente, ela reúne todas essas deusas e ainda mais. Em um sentido diferente, considera-se que ela inclui cada aspecto da feminilidade humana; incompreensivelmente, ela combina a pureza virginal, a maternidade protetora e afetuosa, a paixão sexual, livre libertina e a espontaneidade de uma deusa do amor físico, sempre disponivel. Metaforicamente, ela cria a vida como a deusa Mãe Terra: toda a vida vem dela e a ela retorna. Ela protege e cuida de seus filhos dependentes com uma lealdade maternal e profunda. Ela nunca deixa de satisfazer os desejos sexuais mais fortes de seus mais ardentes amantes. É honrada, respeitada e protegida por seus adoradores e protetores que dão suas próprias vidas por ela. Eles são os membros do culto à Madona Negra e quantos templários e trovadores também serão seus seguidores secretos? As Madonas Negras são encontradas, dentre as mais famosas, nos santuário de Altotting, na Baviera alemã e no de Czestochowa, distante 90 km de Varsóvia, Polônia. [Trecho extraído do livro intitulado Templários, de Lionel Fanthorpe e Patricia Fanthorpe]. 
batalha, os indômitos templários viviam o seu orgulhoso lema: "Os primeiros a atacar e os últimos a se retirar!"

E nesses territórios devastados pela guerra, as terras do Oriente Médio, eles ouviram falar: histórias sobre o poder, a riqueza, as glórias e a sabedoria de Salomão.

Outro candidato é Carlos Magno nesta lista de guardiões pré-templários que se perderam nas brumas da História da Humanidade. Nascido no Reino da Austrásia, hoje parte da Alemanha, seu título alemão era Karl der Grosse e os franceses o chamavam de Charles Le Grand, enquanto em latim ele era Carolus Magnus. Existem historiadores que o consideram o mais carismático e o mais iluminado deste elenco.

Carlos I do Sacro Império romano e Carlos I, da França, e seus feitos se aproximaram da multiplicidade de seus títulos. Ele era filho mais velho de Pepino, o Breve, o Moço, conhecido formalmente como Pepino III. Ele e Carlomano, seu irmão, foram administradores do palácio para a Dinastia Carolíngia, que viriam a substituir. Carlomano e Pepino eram filhos do poderoso Carlos Martel que se assegurou que seus filhos tomassem o controle sobre aquilo que os merovíngios - enfraquecidos militar e politicamente - não pareciam capazes de administrar. O Vaticano indubitavelmente guarda muitos segredos antigos e estranhos, incluindo o que acontecera entre o Papado e a nova Dinastia Carolíngia. O Reinado de Carlos Magno foi repleto de riquezas para a ciência clássica natural antiga como a Matemática, a Filosofia, a Medicina, a Lógica e o Direito.

Por último, Leonardo Da Vinci qualificado pelos historiadores e admiradores como o maior gênio de todos os tempos. Além de seus dons quase celestiais, conhecedor dos segredos templários incluídos em suas telas, Da Vinci cantava tão bem, uma vez ter voz bela ao canto, quanto aprendiz de pintura e escultura na oficina de Varrochio. Era homem de grande força física, reforçada com dieta estritamente vegetariana, parcialmente estimulada por seu amor aos animais. Várias vezes o gênio - protegido da família florentina Médici - comprava pássaros presos em gaiolas, para depois soltá-los, acompanhando-os até os seus desaparecimentos no horizonte da vida. Era amigo do Rei francês Francisco I e dele se tornou seu principal arquiteto, engenheiro e artista. A famosa pintura de Milão, intitulada $A$ Última Ceia, deu margem aos princípios de pesquisa do Autor Dan Brown no livro $O$ Código da Vinci, repassado para filme homônimo de 2009.

Todo esse elenco e muito mais, que neste momento não cabe relatar, é composto de homens que, pretensamente, pertenceram à Ordem Centenária dos Templários, de sabedoria incrível aos padrões da Humanidade, extremamente dignos, de conduta irrefutável aos tempos em que viveram e nível intelectual sobre-humano. Homens que criaram métodos de intercâmbio financeiro, sendo considerados os pioneiros da origem às instituições bancárias que enriqueceram o Vaticano, o qual, hoje, além de ser um país poderoso, apesar da pequena dimensão territorial, é a sede do Governo católico, comandado pelo representante de Deus na Terra, o Papa. 


\section{O Direito Canônico}

10.1. Histórico. Na trajetória da História da Religião, desde os tempos da Igreja primitiva havia entre os pioneiros cristãos o hábito de se realizar coleções de sagrados cânones, no intuito de facilitar o conhecimento e, principalmente, uso e observância de conduta aos primeiros ministros sagrados. Em 633, o IV Concílio de Toledo prescrevia depois da restauração da disciplina da Igreja que os sacerdotes deveriam conhecer as Escrituras Sagradas e os cânones. A Igreja, na época, estava desvinculada do arianismo (doutrina de Ário, que recebeu o nome herdado do famoso heresiarca de Alexandria, 280-336; doutrina esta segundo a qual Jesus Cristo era Espírito de natureza intermediária entre a divindade e a Humanidade). $\mathrm{O}$ iniciador de todo esse cômputo foi o Papa Celestino. E no decorrer dos dez ou doze primeiros séculos floresceram em diversos lugares coletâneas de leis eclesiásticas, a maioria compilada por cristãos e em caráter particular, que continham nomes emanados dos Concílios e dos Romanos Pontífices.

No século XII,

o acervo foi composto ou reunido pelo monge Graciano, no intuito de se estabelecer a concordância das leis e também das coleções. Graciano colocou-os em ordem de importância e criteriosa regra de temas e assuntos pertinentes ao Catolicismo. Esse conjunto de computação veio a se intitular Decretum Gratiani que, de fato, veio a constituir a primeira parte da grande coletânea de leis da Igreja que, em parâmetro ao Corpus Juris Civilis, do imperador Justiniano, foi chamado de Corpus Juris Canonici.

O Corpus Juris Canonici que continha as leis durante o período de quase dois séculos - elaboradas pela Suprema Autoridade dos Romanos Pontífices foi auxiliado pelo Decreto de Graciano, o qual, por sua vez, continha as leis anteriores e que consta do Liber Extra, de Gregório IX, do Liber VI, de Bonifácio VIII, das Clementinas (coleção de Clemente V) promulgadas pelo Papa João XXII bem como das Extravagantes deste Pontífice e das Extravagantes Communes que são Decretos de vários Romanos Pontífices nunca reunidos em autêntica coleção. O Corpus do Direito da Igreja latina possui similaridade, de algum modo, ao Syntagma Canonum ou Corpus Canonum da Igreja grega.

Cumpre salientar que as leis posteriores, do tempo da Reforma católica dadas pelo Concílio de Trento, promulgadas, posteriormente, por vários Dicastérios da Cúria romana, também nunca foram reunidas em coletânea única. E no Concílio do Vaticano I, bispos solicitaram para que se fizesse nova e única coletânea de leis, no intuito de se poder dar, com maior certeza e segurança, à Cúria Pastoral do Povo de Deus. Essa 
tarefa foi iniciada, posteriormente, pelo Papa Pio X, sucedido depois pelo Papa Bento XV que a terminou, depois de vinte anos em sua elaboração, em 27 de maio de 1917, entrando em vigor a 19 de maio de 1918, sendo o Direito Universal desse Código Piobeneditino muito bem aceito na maioria de todos os membros da Igreja não-só pelo consenso como, também, pela rigorosa e perfeita elaboração de métodos e sistemas religiosos a serem seguidos.

Em 25 de janeiro de 1959, o Papa João XXIII solicitava nova revisão do Código, por meio do Concílio do Vaticano II e a Comissão, composta por vários membros para a revisão do Código de Direito Canônico foi constituída em 28 de março de 1963. Essa Comissão foi acrescida de vários outros membros, inclusos monsenhores, em 17 de fevereiro de 1965, ordenada pelo Papa Paulo VI, sucessor de João XXIII. Lembra-se que o Direito Canônico provém da natureza da Igreja; que sua raiz repousa no poder de jurisdição conferido por Jesus Cristo à Igreja; que sua finalidade deve ser posta na cura das almas para alcançar a Vida Eterna.

E o Novo Código Canônico, com 1.752 cânones, foi publicado na Eterna Roma na Residência do Vaticano, em 25 de janeiro de 1983, exatamente na data de aniversário do Papa João XXIII e declarada pelo Papa João Paulo II.

10.2. Direito Canônico. O professor doutor Salmo Caetano de Souza, desta Academia de Direito, em matéria de sua autoria referendada no final deste trabalho, nos ensina que o cânone e Autor Gianfranco Ghirlanda afirma que, segundo o Papa Paulo VI, a natureza do Direito Canônico ou Eclesial se fundamenta no conceito de sociedade perfeita que traduzimos por sociedade soberana ou independente e no princípio jurídico ubi societas ibi ius.

Trata-se de especificação de cunho filosófico e não-teológico e que, todavia, nunca tal Direito pode ser considerado de modo formalístico e positivístico; isto porque o Direito Canônico ou Eclesial se baseia no princípio evangélico fundamental da Caridade, enquanto que o seu sentido se encontra naquilo que é o Ministério da Igreja, compreendido entre o Corpo Místico/Povo de Deus.

Premissa final: o referido Direito deve interpretar a Lei Divina e a Lei da Consciência e ainda faz parte da ação salvífica de Deus. O Papa João Paulo II também nos ensina que "este mesmo Direito deve traduzir a relação entre justiça, aequitas e caridade no sentido em que, espelhando-se na Justiça Divina, a função judiciária na Igreja deve estar a serviço da verdade e da caridade que, por sua vez, gera a aequitas canônica"

Segundo Ghirlanda, a função do Direito Canônico "é a de ajudar o homem na superação do seu individualismo e abri-lo à sua vocação pessoal e comunitária em um dualismo, de um lado; a tutela da comunhão eclesial e de outro, a da tutela dos direitos de 
cada fiel, sendo que a função primordial da Igreja é a de ser o espelho da justiça (speculum iusticiae) na tutela dos direitos fundamentais do homem"

O professor Salmo Caetano na matéria intitulada Igreja católica: forma de governo e regime político, publicada na Revista da Faculdade de Direito da Universidade de São Paulo, nos dá uma síntese de suma importância, nos ensinando que:

[...] o poder da Igreja se estrutura na sociedade de modo soberano, porque fundado pelo próprio Cristo e, por isso, exerce seu poder de modo originário e autônomo, o que vale dizer, independente, com capacidade para determinar a própria competência; é uno e universal, porque a ação da Igreja não conhece fronteiras, ou seja, sua geopolítica é de espectro global; é perene, porque a sua missão salvadora só se esgota quando seu fundador voltar e, portanto, sua ação dura até o final dos tempos; possui uma autoridade organizada hierarquicamente, tendo o Papa como Suprema Autoridade da mesma; é de natureza sobrenatural e espiritual, pois emprega meios sobrenaturais - Jesus Cristo é a Sua Graça - para alcançar fins espirituais, a saber: a salvação das almas; é dotado de leis próprias, principalmente o Código de Direito Canônico, para o seu autogoverno e para a sua relação com os Estados, fundamentais no conceito de Igreja como sociedade perfeita (soberana ou independente) e no princípio jurídico ubi societas ibi ius; é Corpo de Cristo porque estabelece uma unidade íntima entre os seus membros, a saber: o Espírito Santo, além da cooperação entre os mesmos; é Povo de Deus, porque se encarna em comunidade formada por homens e, por isso, é social e histórica.

Em Curso de Direito Canônico, de autoria do professor doutor de Salamanca, Espanha, Rafael Lhano Cifuentes, deparamos com a seguinte definição:

[...]define-se o Direito Canônico como o conjunto de normas jurídicas, de origem divina ou humana, reconhecidas ou promulgadas pela autoridade competente da Igreja católica, que determinam a organização e atuação da própria Igreja e de seus fiéis, em relação aos fins que lhe são próprios.

Note-se que a Igreja, em toda a sua totalidade, não pode de maneira alguma ser compreendida ou interpretada, quando observada do lado de fora; tem diferentes aspectos, dentre eles, a saber: histórico-cultural, sociológico, cultural, filosófico, espiritual e jurídico. E quem a observar fenomenologicamente como historiadores, sociólogos, filósofos, espiritualistas e juristas, com certeza nunca conseguirá chegar ao seu conteúdo que é o de captar suas notas essenciais, porque as diferentes facetas que ela apresenta apreciadas estritamente sob o ângulo de uma determinada ciência nos dão ensejo a 
interpretações fragmentárias e estas, no momento em que se pretende elevar a lei geral, facilmente têm, como premissa final, o ato de desvirtuar a verdade.

$\mathrm{E}$ isto aconteceria se considerássemos a Igreja como resultado de um determinado aperfeiçoamento das religiões pré-cristãs, conforme alguns pretenderam. $\mathrm{Ou}$, ainda, como suporte de certa doutrina filosófica. Ou, como apêndice natural de uma concepção da vida ligada a tempo histórico. Por último, como simples instituição de Direito.

\section{A Igreja e o Direito Canônico}

A Igreja tal como é inserida na História da Humanidade se apresenta travestida de perfis históricos, sociológicos, culturais, filosóficos e jurídicos; todavia, a Igreja não quer ser reconhecida empiricamente, sob o prisma dessas manifestações. Inserido nela, existe conteúdo interno eminentemente espiritual, o que dá ensejo a todas as suas manifestações externas e conforme estudos de H. Schmaus em Teologia Dogmática, referendado no final deste trabalho:

[...] Existe na Igreja um conteúdo interno, espiritual e sobrenatural que dá sentido a todas as suas manifestações externas e só através dele conseguiremos ter uma visão completa de todas as suas características. Precisamente por isto, para se ser íntegro e preciso no julgamento, é necessário, antes de tudo, ver a Igreja à luz da sua verdade interna, daquilo que ela mesma diz querer ser.

Além do fato dos que pertencem à Igreja estarem unidos entre si, formando um só corpo espiritual, místico, cuja cabeça é Jesus Cristo, como vimos acima, a Igreja não se resume a uma pura comunidade de Espírito, mística e interna. Ela está formada de homens e para homens, os quais constituem externamente uma verdadeira comunidade social e histórica: o Povo de Deus. Especificamente esta designação se assemelha ao do Povo israelita como povo peregrino que atravessa o Deserto por cima de toda uma divisão político-cultural histórica como, também, racial à procura da cidade eterna e vivendo em ordem hierárquica no intuito da realização do Reino de Deus. Reporto aqui ao leitor, neste assunto, à matéria intitulada $O$ Judaísmo. O Direito Talmúdico referendada no final.

E não nos é possível conceber uma organização social seja qual for a sua natureza - sem que nela imperem normas jurídicas capazes de regulamentar as relações recíprocas de seus membros. E seguindo a doutrina clássica da sociabilidade do Direito ("ubi societas, ibi ius") chega-se à conclusão do caráter jurídico da Igreja.

O Papa Paulo VI em Alocução, de 26 de maio de 1966, comenta que:

[...] há quem quereria que a Igreja fosse só espiritual e, portanto, invisível; para quem pensa assim, só essa Igreja seria de origem divina sem levar em conta, de nenhum 
modo, a conseqüência lógica de que uma Igreja invisível não é Igreja. A Igreja, pelo contrário, é precisamente uma sociedade jurídica, organizada, visível, perfeita ... Assim quis o Senhor a sua Igreja.

Percebe-se a interferência mediadora do sábio Papa Paulo VI, porque ele caminha ao encontro de uma indiscriminada mentalidade antijurídica e afirmando que esse modo de raciocínio se tratava de comportamento totalmente antieclesial e em Alocução, de 17 de agosto de 1966, se pronuncia:

[...] sabemos muito bem que, em muitos lugares, se vê com antipatia a atividade legisladora da Igreja como se fosse contrária à liberdade dos filhos de Deus, antiética do espírito do Evangelho e como se estorvasse a espontânea expressão dos carismas próprios do Povo de Deus e detivesse o desenvolvimento histórico do organismo eclesiástico que fica proscrito e atrasado em relação ao desenvolvimento histórico da sociedade temporal. Mas não vemos como a Igreja católica, se quer permanecer fiel, ser conseqüente com os princípios construtivos dados por seu Divino Fundador, pode prescindir de dar-se a si mesma um Direito Canônico: se a Igreja é uma sociedade visível, hierárquica, comprometida numa missão salvadora, que não admite senão uma unívoca e determinada realização, que deve ser conservada rigorosamente e defendida apostolicamente, responsável pela saúde dos próprios fiéis e da evangelização da Revelação e das necessidades que brotam continuamente da sua vida interior e exterior.

Lhano Cifuentes complementa essas ponderações do Papa Paulo VI, quando relata que o aspecto jurídico da Igreja é o de poder defender não apenas uma de suas prerrogativas essenciais, mas na insistência da necessidade do Direito, o caminho seguido foi o de fazê-lo principalmente por ser ele um extraordinário veículo de ordem, de renovação e de liberdade.

\section{A Teologia e o Direito Canônico}

A Teologia açambarca o estudo das questões referentes ao conhecimento da divindade, de seus atributos e relações com o mundo e com os homens e à verdade religiosa; e enfatizando o estudo racional dos textos sagrados, dos dogmas e das tradições do Cristianismo. Segundo Santo Tomás em Summa Teológica, é uma ciência especulativa e prática que estuda, à luz da Revelação Divina, Deus e as criaturas na sua relação com Ele, bem como a conduta moral do homem em ordem ao seu último fim.

Em parâmetro ao Direito Canônico, este regulamenta a sociedade externa formada por homens que vivem em uma mesma fé acerca do Pai Eterno e que seguem os 
mesmos preceitos e critérios morais, no intuito de atingirem o seu último fim. Não há o que refutar que, entre o Direito Canônico e a Teologia, pela lógica e descrição de seu perfil entre a ciência Canônica e Ciência Teológica -, que exista estreita correlação e isto nos mostra a razão de ser de muitos preceitos que parecem surpreendentes para quem só está envolvido com o Direito Civil. Mesmo porque, o Direito Canônico na busca da inserção na vida sobrenatural da Igreja, no intuito da salvação de almas, chega a regulamentar, juridicamente, as matérias intrínsecas ao sobrenatural, dentre elas as do sacramento. Ressalta-se que o Direito Canônico está vinculado à Revelação Divina, estudada pela Teologia e dela recolhe os seus princípios; todavia, os aplica segundo métodos e técnicas subjetivas, isto é, dele próprio.

Enfim, a distinção entre a Teologia e o Direito Canônico se diferencia, porque a Teologia considera as atividades humanas preferencialmente por meio da premissa de motivos internos e em conformidade com os preceitos morais; e o Direito Canônico é o avesso, uma vez que avalia a conduta humana nas suas relações de alteridade, isto é, relações inter-humanas e externas, segundo critérios jurídicos que são processados no foro externo. Cumpre salientar que no Direito não há julgamento, de algum modo direto, das intenções internas, como a Moral; todavia, das relações humanas externas, em consonância com uma norma jurídica objetiva promulgada pela autoridade competente. E enfatizase que o jurídico na Igreja não deve se imiscuir no Teológico, dando margem à perda de sua própria consistência e acarretando uma mistura híbrida de preceitos teológicos com jurídicos e morais. É necessário que o Direito na Igreja, em benefício da eficácia e nitidez da norma jurídica, mantenha - autonomia própria tanto como Ciência quanto corpo normativo, sem perder o seu caráter exclusivo de instrumento jurídico.

\section{O Direito Civil e o Direito Canônico}

Mister se faz comentar que, tendo o Direito Civil e o Canônico como elemento característico a juridicidade e, portanto, a participação de denominador comum na mesma ordem da justiça, é óbvio que tanto um quanto o outro se interliguem vigorosamente; todavia, não deixam de existir diferenças profundas, uma vez o Direito secular tende a regular a ordem da justiça na sociedade temporal e o Direito Canônico está contemplado a estabelecer a justiça no âmbito da Igreja, no intuito de alcançar o bem comum sobrenatural dos fiéis.

Na dualidade Ética e Caridade, as quais não devem ser confundidas com a justiça, fundamento do Direito secular, encontra-se um determinado papel que é o de servir tanto na esfera civil quanto na eclesiástica e cumpre salientar -, nas devidas proporções, porque em ambas a sua presença é igualmente necessária.

Mediante analogias, como também diferenças, entre o Direito Canônico, Direito Civil e a Teologia observamos que no Direito da Igreja - no âmbito panorâmico da 
Ciência Jurídica -, surgem características estruturais e funcionais, as quais singularizam um modo estável de se compará-los. São elas: estabilidade, flexibilidade e universalidade.

A flexibilidade vem a ser uma qualidade jurídica que visa adaptar normas às circunstâncias individuais no intuito de se conseguir o maior bem das almas; a estabilidade se destaca em sua característica na estreita relação tanto com a Teologia quanto com o Direito Divino Positivo e a universalidade tem como premissa maior a unidade orgânica de um Direito que mantém nexo de continuidade, desde a Era Apostólica até os dias atuais da História da Igreja católica.

As contribuições que o Direito Civil prestou ao Direito Canônico têm uma história densa e contínua, como nos ensina Rafael Lhano Cifuentes que nos apresenta ilustrações:

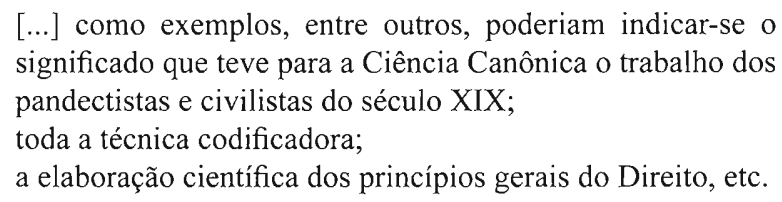

Influência constante que permitiu ao Papa Leão XIII dizer: "Ius canonicum sine iure civile perinde esse ac theologiam sinc philosofia"

A presença do Direito Canônico, inserida nos estudos de Direito Civil, não encontra a sua razão de ser apenas nessa mútua interação de influências, uma vez o fato de o Direito Canônico possuir o perfil de matéria clássica que repercute, tradicionalmente, grande parte de currículos universitários de muitas faculdades do mundo todo, enfatizando Europa, Ásia e América. Baseia-se em necessidade que parte da realidade social, jurídica e religiosa de vários países católicos.

Dependendo da política adotada em certos países, enfatizando-se, mais uma vez os católicos, conclui-se da conveniência que apresenta o estudo do Direito Canônico em faculdades de Direito. No Brasil, na Pontifícia Universidade Católica - que possui um leque dessas instituições de Ensino em várias cidades do País, inclusive nos anos 70 e 80 consideradas de alto nível educacional são poucas as Unidades que têm em sua grade de cursos de graduação os ensinamentos do Direito Canônico.

E não nos é difícil verificar que em legislação como a italiana, institutos jurídicos são totalmente regulamentados pelo Direito Canônico, por meio do sistema de remissão ou reenvio, ou que em países como o Brasil e muitos outros se reconhece valor jurídico a determinados atos como o consentimento matrimonial, realizados sob o amparo e formalidades do Direito Canônico. É interessante observar que, no âmbito familiar brasileiro, o casamento tem de ser realizado tanto em cartórios quanto em solenidades religiosas, principalmente para a Igreja e fiéis católicos. Neste último ato, caso não haja, nos faz parecer que o casamento não foi consumado! 
E assim, tendo presente a constituição, os meios e fins que se encontram na origem e na essência da Igreja - considerando-a no seu conjunto - ela se torna uma corporação institucional, dotada de soberania originária e autônoma movida de capacidade subjetiva pública e privada, no intuito único e exclusivo de conseguir o bem comum sobrenatural da santificação dos fiéis. Nota-se, segundo o jurista Del Giudice em Nociónes de Direito Canónico que, "ao se mencionar o termo corporação institucional, se quer indicar que o substrato social está constituído por uma coletividade de homens que cooperam na consecução de um mesmo fim"

\section{O Estado e a Igreja}

Historicamente, a Igreja foi a primeira autoridade religiosa a defender a distinção entre a esfera temporal e a espiritual. A soberania do Estado está reiteradamente defendida pela Igreja, a qual reconhece ao Estado no que tange diretamente negócios temporais em uma perfeita independência.

A devida separação entre Igreja e Estado e o conceito de liberdade das consciências não foi um valor conseguido pelo Liberalismo, mas um direito reivindicado justamente pela Igreja que, segundo J. Leclerq, "uma conquista genial do Cristianismo e que deveria ser reconhecida por todos como um dos elementos primordiais do progresso da Humanidade"

E com a evolução dos tempos constrói-se uma sólida, robusta e plena soberania do Estado no seu terreno que não pode nem deve ser invadida pela Igreja, invocando motivos de ordem sobrenatural. E esses motivos não deixarão de ser paliativos de um clericalismo que rebaixa o sobrenatural até o nível do temporal. O Papa Pio XI com relação a esta questão assim se manifesta:

A Igreja nem quer nem deve imiscuir-se, sem justa causa, na direção das coisas estritamente humanas.

Em tempos modernos, a maioria dos Estados é independente, tem competência totalmente desvinculada da Igreja. Todavia, não se deve esquecer que nos primórdios dos tempos, a Igreja se encontrava mergulhada em uma concepção da sociedade e da política que considerava o poder civil e o religioso como realidades correspondentes, que se compreendiam mutuamente. Os chefes das religiões eram ao mesmo tempo magistrados do Estado.

A evolução, muito morosa, chegou precisamente na Idade Média, época do surgimento do Renascimento; período, aliás, em que começou a se formar a consciência da nacionalidade e do Estado, com propensão à independência, o qual rompia num pluralismo de soberanias, o monismo da Cristandade. 
E indubitavelmente esta consciência social da nacionalidade representa um progresso na História da Humanidade; todavia, a supervalorização da idéia de nacionalidade degenerou em nacionalismo, acarretando o nascimento do absolutismo estatal que provocou conseqüências importantes a respeito das relações com a Igreja. $O$ absolutismo estatal recolheu a tese mantida por Marsillo de Pádua em sua obra intitulada Defensor Pacis, para afirmar a competência direta do soberano em toda a vida social e, portanto, na vida religiosa. Essa doutrina foi ampliada e elaborada politicamente de maneira compacta por Jacobo I e mais tarde pela corrente política da Teologia protestante.

Voltando um pouco, Jacobo I fundamentava, teologicamente, o seu absolutismo em estranhas teorias religiosas, nas quais situa o poder real por cima do poder do Papa e o poder real seria um direito divino ilimitado e totalmente absoluto.

Em outra esfera, a Igreja mantinha gravada em sua essência a doutrina de Jesus Cristo que dividia em duas metades aquele monismo político-religioso do mundo pagão. E segundo Foustel de Coulanges,

a partir do Cristianismo toda uma metade do homem ficou emancipada do Estado, fato este que deu margem à fonte de onde emanou a liberdade do indivíduo.

\section{A separação definitiva da Igreja e do Estado}

Durante a Idade Média, entendia-se que o povo europeu deveria se submeter aos preceitos da Lex divina, estabelecidos nas revelações feitas por Deus, das quais a Igreja era depositária. E aos preceitos da Lei positiva, que os homens formulavam, adaptando os princípios da Lex naturalis à sua comunidade.

$\mathrm{Na}$ verdade, o Direito era, sobretudo, consuetudinário e emanava do mais forte, tanto que a palavra iustitia se alastrou a ponto de designar o conjunto dos poderosos senhorios que estava diretamente tutelado pela Igreja católica, cujos clérigos também eram senhores de espada e exerciam poderes temporais. Lembre-se que os reis e imperadores não eram chefes de Estado; todavia, na função de príncipes que lhes prestavam a hominium ou homagium, como vassalos, porém tinham direitos soberanos e seu próprio senhorio territorial.

Como se pode apreender das lições do filósofo, historiador e economista político de Praga, Karl Kautsky (1854-1938), que viveu em Viena e Londres, Autor que considero eterno professor de Filosofia, além de seu exímio didatismo, com o qual contempla os estudiosos da História da Humanidade:

[...] na Idade Média não havia autoridade da Lei e Direito, exceto o capricho e a vontade dos senhores feudais e aos soberanos cabia a investidura dos bispos, que lhes deviam $a$ 
hominium e executar serviço feudal, vassalos, detentores de feudos seculares.

O conceito de crime político sempre dependeu do conceito de Estado assim como da fonte do Direito, enquanto ordenamento das relações sociais que reconhece a legitimidade da lei ou do costume, nunca até então com a interferência ou intervenção da Igreja. No final da Idade Média, os Estados teocráticos, entre os judeus, obedeciam à hagadá e hajachá, teologia e Lei do Judaísmo como, também, os islâmicos regidos pelo Qur'an, Alcorão.

As infrações religiosas se confundiam com os crimes políticos e punidos com a pena de morte. Por último, no Sacro Império romano-germânico as noções do Direito Divino (Lex divina) e do Direito Natural (Lex naturalis) se misturaram e assentaram padrões normativos da Política em meio de crônico conflito de jurisdição entre o Papado e o imperador; posteriormente, entre o Papado e as monarquias nacionais que, na época, estavam a emergir.

Após a época da Inquisição, a Igreja católica e o regime feudal se entrelaçaram e o Direito se confundiu com a Teologia e a heresia equiparada ao de traição e punível com a pena de morte. Independentemente de qualquer julgamento, a queima de hereges ocorria em toda a Europa, acentuando-se em Soissons, França, em 1114 e em Colônia, Alemanha, em 1143. Na época de Inocêncio III, o Papa mais poderoso da Idade Média, os cátaros ${ }^{7}$ foram brutalmente reprimidos, perseguidos e queimados na fogueira, considerado Período do Terror, porque inclusive eram queimados vivos.

A doutrina do Papa: o poder espiritual se identifica com o civil e a heresia se configurava como um delito tanto eclesiástico quanto civil.

Terminado o Período do Terror, durante o Renascimento o homem se torna mais consciente do valor da personalidade e da liberdade individual, advindas e baseadas nesta idéia, instituições renascentistas de perfil tomista. Havia correntes no âmbito do Renascimento, contrárias entre si, nas quais se destacaram Tomás Morus, Luiz

\footnotetext{
Os cátaros floresceram na França no século XI até que o Rei Roberto II, o Pio, ordenou que trinta deles fossem queimados vivos em praça pública no ano de 1022 . Todavia, o movimento chegou ao ápice no começo do século XIII e, nessa época, muitos franceses do Sudoeste eram cátaros. Eles constituíram uma civilização autônoma, cuja área na qual viviam não estava sujeita aos impostos do Reinado francês, tornando-se, assim, uma região independente conhecida como Occitania ou D'oc. O povo falava occitano, uma língua derivada do latim como o francês, e ainda é falada naquela região até nos dias atuais. $\mathrm{O}$ maior baluarte dos cátaros foi Montsegur, uma dramática formação rochosa no contraforte dos Pirineus; ali, em 1200, dois cátaros, Raymond de Mirepoix e Raymond Blasco pediram e conseguiram aprovação para reconstruir uma velha fortaleza. Os cátaros tinham o título de parfaits, pessoas perfeitas, membros do fechado círculo da fé cátara. A fé cátara é assemelhada aos gnósticos, antes deles, que acreditavam que a salvação consistia em remover de si todo o apego ao mundo material que, intrinsecamente, era um mal; a pobreza era louvada e o sexo considerado como um ato vinculado às obras do Diabo. O poder dos cátaros foi extinto em 1242, quando a maioria foi condenada à fogueira e executados vivos.
} 
Vives, Bocaccio e Maquiavel, num conjunto atualmente denominado Liberalismo, que por ser um conglomerado de vários fatores filosóficos, culturais e sociais não aparece, historicamente, como frente única e compacta nem oferece um determinado pensamento de doutrina precisa.

$\mathrm{Na}$ área filosófica cria-se um individualismo que encontra sua raiz no cogito ergo sum, de Descartes que pretende, seguindo a linha-diretriz do Renascimento, subministrar "a cada qual os meios de achar em si mesmo, sem nada pedir a outrem, toda a ciência que lhe é necessária para a orientação de sua vida". Essa idéia ou pensamento espraia-se por meio de Kant, Fichte e Schelling para se achegar ao absolutismo de idéia em Hegel e a dialética de Hegel é a ponte entre Kant e Marx em que o absoluto da idéia troca-se pelo absoluto da matéria, chegando, finalmente, ao materialismo histórico. Esta foi a base filosófica que acompanhou o desenvolvimento da concepção social e econômica do Liberalismo.

Todavia, a estrutura mais profunda do homem eminentemente religiosa, foi exatamente em relação à Igreja e à Religião onde o Liberalismo teve conseqüências radicais, porque se incitava a supressão no plano individual da idéia objetiva de Deus.

Conforme nos ensina Rafael Lhano Cifuentes:

Nega-se toda possível ordem objetiva social ou jurídica querida por Deus. E fazendo a Deus à imagem e semelhança de cada homem, cria-se também o Reino de Deus no mundo ao sabor dos próprios gostos.

Isto é, desvirtua-se o valor da Igreja - como organização jurídica fundada por Cristo - para sublinhar o aspecto individual da Religião. E a Religião se converte em um assunto privado; passa a ser uma comunicação direta e individual com Deus, alheia a toda manifestação social.

Neste ponto, o princípio prático do Liberalismo é o de exigir de cada cidadão o esquecimento de sua condição cristã na Assembléia ou no Parlamento, para depois recuperá-la, principalmente quando estiver no recinto dos templos da Igreja. E diferentes sistemas sociais e políticos propugnam essa concepção liberal do Estado e da Religião; dentre eles, o liberalismo radical, moderado e catolicismo liberal. Todavia, todos eles, coincidem no pensamento ou na prática da tese que reclama uma separação completa da Igreja e do Estado.

Ao Estado só interessa a pessoa humana enquanto cidadão temporal e não enquanto cidadão fiel às determinadas crenças religiosas que têm convicções particulares totalmente sem relevância à vida pública. E pela mesma razão a Igreja deve ser considerada como mera associação sem direitos especiais, com a qual o Estado deverá manter completa independência, excelente harmonia e de absoluta separação, uma vez ambas as esferas possuírem finalidades diferentes ou linguagens próprias, individuais. 
16. Código Canônico

O Código de Direito Canônico é assim constituído:

Livro I, Das Normas Gerais que abrange desde o Título I referente às leis eclesiásticas até o Título XI que açambarca o tema Do Cômputo do Tempo.

Livro II, tendo como tema o Povo de Deus, constituído de três partes:

I Parte: Dos Fiéis;

II Parte: Da Constituição Hierárquica da Igreja, composto de duas seções,

a saber:

Seção I: Da Suprema Autoridade da Igreja;

Seção II: Das Igrejas Particulares e das Entidades Que as

Congregam.

III Parte: Dos Institutos de Vida Consagrada e Sociedades

de Vida Apostólica, composto de duas seções, a saber:

Seção I: Dos Institutos de Vida Consagrada;

Seção II: Das Sociedades de Vida Apostólica.

Livro III, tendo como tema Do Múnus de Ensinar da Igreja, desde o Título I referente ao Ministério da Palavra de Deus até o Título V que açambarca Da Profissão de Fé.

Livro IV, tendo como tema Do Múnus de Santificar da Igreja, composto de três partes, a saber:

Parte I: Dos Sacramentos;

Parte II: Dos Outros Atos do Culto Divino; e

Parte III: Dos Lugares e Tempos Sagrados.

Livro V. tendo como tema Dos Bens Temporais da Igreja, desde o Título I, Da Aquisição dos Bens, até o Título IV, Das

Vontades Pias em Geral e das Fundações Pias.

Por último, Livro VI que aponta o tema Dos Processos, dividido em três partes, a saber:

I Parte: Dos Juizos em Geral;

II Parte: Do Juízo Contencioso, composto de duas seções:

Seção I: Do Juizo Contencioso Ordinário;

Seção II: Do Processo Contencioso Oral.

III Parte: De Alguns Processos Especiais;

IV Parte: Do Processo Penal;

V Parte: Do Modo de Proceder nos Recursos Administrativos e na Instituição e Transferência de Párocos, composta de duas seções:

Seção I: Do Recurso contra Decretos Administrativos e Seção II: Do Processo para a Destituição e a Transferência de Párocos. 


\section{Conclusão}

Ao se voltar o pensamento para trás, observa-se a trajetória difícil que os cristãos primitivos percorreram, punidos sem julgamentos e sob cruéis perseguições que são apresentadas nos episódios da História da Humanidade enfatizando-se o terrível período da Inquisição que, nesses quadros de reminiscências, os mais famosos são os fatos de muitos pretensos hereges terem sido lançados à fogueira, ainda vivos!

A sobrevivência cristã adveio do sacrifício que homens e mulheres vivenciaram na evolução dos tempos; os cristãos primitivos sofreram todas as ações externas que o imolavam; todavia, permaneceram fiéis ao Messias. O cristão moderno não se preocupa com arenas, leões, cruéis perseguições nem tampouco se esconde para o estudo evangélico trazido por ordem de Deus. O cristão moderno, atualmente, vive nas metrópoles, em meio às indústrias, aos supermercados, ao ambiente jurídico eletrônico e ao direito à liberdade de pensamento e a crença religiosa; grande parte vive em Estados Democráticos de Direito; procura estudar, trabalhar e se esforçar para o aprimoramento, que só será válido com a vivência da Lei do Amor. Desde que o homem é homem, a existência de Deus é o grande desafio às convicções humanas.

Após anos e anos de perseguição, os cristãos tiveram a interferência divina no século IV a.C. com a decisão de o imperador Constantino I se converter ao Cristianismo e em 320 d.C., o Cristianismo se tornou a Religião oficial do Império romano. E desde então a Igreja católica se fortaleceu, dando margem, nesta evolução, à escolha do primeiro bispo da cidade romana como, também, ao primeiro Papa: São Pedro, um dos discípulos mais próximos de Jesus Cristo, depois da Senhora Maria Madalena, notável mulher, cuja biografia tem de ser arrebatada pelos cristãos modernos.

Hoje, a Igreja católica é a mais procurada pelos habitantes deste planeta, embora haja problemas internos na sua constituição. Das várias controvérsias que tem perseguido a Igreja católica, a mais importante e a que tem deixado os últimos papas constrangidos [leia-se Papa João Paulo II e Bento XVI], é a questão dos padres pedófilos, enfatizando a Igreja católica dos EUA e a do Canadá. Série de casos ocorridos mereceu destaque da Imprensa na década de 90; porém, as referências à ocorrência do gênero são muito antigas. O quadro mais chocante foi o do Canadá entre os anos de 1940 e 1960, no tocante ao escândalo dos órfãos de Duplessis.

$O$ episódio se refere às crianças que foram internadas em orfanatos canadenses católicos e erroneamente classificadas como doentes mentais e sujeitas a tratamentos totalmente inadequados ou mesmo a abuso direto. $\mathrm{Na}$ verdade, elas foram abusadas sexualmente pelos padres dirigentes do orfanato de perfil canadense. Cumpre salientar que o principal foco da crítica pública não foi versado aos que efetivamente praticaram os abusos; todavia, dirigido à hierarquia da Igreja católica, acusada de não tentar levar os acusados à justiça, incluso até de encobri-los. 
E assim, o termo padre pedófilo entrou para o vocabulário popular e a Igreja católica sofreu crise muito séria, quando, inclusive, suas finanças tiveram queda de donativos acentuada como, também, em virtude dos processos judiciais, mediante as conseqüentes indenizações.

No Brasil, raríssimos casos aconteceram, pois se há padre pedófilo, a Polícia Federal brasileira - considerada a melhor do mundo em sua exímia atuação -, teria dados estatísticos cadastrados e o combate eficaz.

Outra discrepância no País - por ser considerado o de maior número de católicos do mundo - em relação ao comportamento social e moral é o de a Igreja católica não reconhecer o uso de preservativos na profilaxia contra a Síndrome da Imunodeficiência Adquirida (Aids/Sida); além da não-concordância à união homoafetiva, trazendo críticas contundentes e a perda de fiéis jovens que acorrem às igrejas menores. Por último, o aborto em que a maioria é contra tal prática e nesse item trazendo pontos favoráveis à Igreja católica. A título de exemplo, o Espiritismo não aceita o aborto: abomina!

O atual Papa, Bento XVI, admitiu em livro lançado, em novembro deste ano de 2010, pela Livraria Editora Vaticana, sob o título Luz do Mundo: o Papa, a Igreja e os Sinais dos Tempos que em alguns casos singulares o uso da camisinha pode ser justificado, indicando, assim, possível mudança na postura da Igreja sobre este tema. O mesmo Papa, ainda, citou como exemplo o uso de preservativos na prostituição masculina e feminina. Essa assertiva vem de encontro à péssima declaração, em 2009, na África, quando o Papa se pronunciou alegando que preservativos não solucionariam a questão e ainda agravariam a problemática em tela. Por meio deste comentário público, o Papa Bento XVI recebeu críticas ferrenhas de organizações internacionais como, também, de Governos europeus e de estudantes de Direito, Sociologia, Jornalismo, Filosofia e outros.

Mas esta mudança de tom da Igreja católica já estava prevista desde 2006, quando o porta-voz, o então ministro da Saúde do Vaticano, o cardeal Javier Lozano Barragán se pronunciou no sentido de que, por ordem do Papa Bento XVI, estudos minuciosos da questão de uso de preservativos estavam sendo realizados pelos teólogos em conjunto com cientistas.

Enfim, por meio do Código de Direito Canônico, a Igreja católica em sua trajetória evolutiva está amparada em pautas que requerem cuidados em favor dos fiéis. Tanto o Código Canônico, como a Thorá, o Qur'an, Alcorão, o Evangelho Segundo o Espiritismo são obras incriveis que trazem ao homem os caminhos de uma vida feliz e voltada ao Criador de Todas-as-Coisas: o Pai Eterno, o Deus Único, Espírito de Luz que nos olha atento aos mínimos detalhes de nossa conduta pessoal nesta passagem pelo planeta Terra.

São Paulo, fevereiro de 2010. 
[O autor agradece a colaboração espontânea na revisão deste trabalho à dra. Neurilene Gomes da Silva, servidora do Serviço Técnico de Imprensa, desta Academia de Direito.]

\section{Referências}

ALMEIDA, João Ferreira de. A Bíblia Sagrada. Antigo e Novo Testamento. Revisado e atualizado no Brasil. Edições da Sociedade do Brasil. 2. ed. São Paulo, 1993.

ALTAVILA, Jayme. A origem dos direitos dos povos. 5. ed. São Paulo: Editora Ícone, 1989.

BARY, Théodore de. Sources of Indian tradition. Nova York: Editora Columbia Press University, 1968. v. 2.

BOCK, Darrell L. Os evangelhos perdidos la verdade por trás dos textos que não entraram na Bíblia]: Editora Thomas Nelson Brasil. Título original: "The missing gospels: unearthing the truth behind alternative christianities". Rio de Janeiro, 2007.

CAMPBELL, Alexander. The heart of Indian. Nova York: Editor Alfred A. Knopf, 1968.

CAMPBELL, Joseph. As transformações do mito através do tempo. São Paulo: Editora Cultrix, 1997.

CAMPOS NETO, Antonio Augusto Machado de. O judaísmo. O direito talmúdico. Revista da Faculdade de Direito da Universidade de São Paulo, São Paulo, v. 103, p. 27-67, jan./dez. 2008.

CIFUENTES LHANO, Rafael. Curso de direito canônico. São Paulo: Edição Saraiva, 1972.

CÓDIGO DE DIREITO CANÔNICO: Codex Iuris Canonici, promulgado por João Paulo II, papa; tradução. In: CONFERÊNCIA NACIONAL DOS BISPOS DO BRASIL. São Paulo: Editora Loyola, 1983.

COÊLHO, Sacha Calmon Navarro. A história da mitologia judaico-cristã [uma teoria sobre as religiões reveladas servidas por uma antologia comentada de autores seletos]. São Paulo: Editora Noeses Ltda., 2010.

CROWLEY, Roger. 1453: A Guerra Santa por Constantinopla e o confronto entre o Islã e o Ocidente. Tradução de Rogério Bettoni. São Paulo: Editora Rosari, 2009.

DE LA HERA, A. Introducción a la ciencia del derecho canónico. Madrid: Ediciones Espanõlas, 1967.

DE VAUX, Roland. Les Institutions de l'Ancien Testament. Paris: Les Éditions du Cerf, 1966. v. 2.

DEL GIUDICE, V. Nociones de derecho canónico. Pamplona: Ediciones Espanõlas, 1956.

EHRMAN, D. Bart. Lost christianities: the battles for Scripture and faiths we never knew [Cristianismos perdidos: a batalha pelas Escrituras e pela fé que nunca conhecemos] Universidade da Carolina do Norte. Oxford University Press. EUA, 2003. 
FANTHORPE, Lionel \& Patrícia. Templários: Segredos e Mistérios, a História por trás do Código da Vinci. São Paulo: Edições Rosari Ltda., 2009.

FERREIRA, Aurélio Buarque de Hollanda. Novo Dicionário da Língua Portuguesa. 2. ed. Rio de Janeiro: Editora Nova Fronteira, 1990.

FOUSTEL DE COULANGES. A Cidade Antiga: estudos sobre o culto, o direito, as instituições da Grécia e de Roma. Editora Ediouro, Rio de Janeiro, 1999.

GARMUS, Ludovico. Evangelho Segundo São Mateus. In: A BÍBLIA. Traduzida diretamente dos originais hebraicos, aramaicos e gregos, com recorrência à Bíblia Hebraica, de Stuttgart e à Edição crítica de Goettingen. Petrópolis: Editora Vozes, 1992.

GATHIER, Emile. O pensamento Hindu. Rio de Janeiro: Editora Agir, 1996.

GHIRLANDA, Gianfranco. Il Diritto nel Mistero della Chiesa. Roma, 1985/1986.

GILISSEN, John. Introdução histórica ao direito. Tradução de A. M. Hespanha e L. M. Macaista Malheiros. Lisboa: Fundação Calouste Gulbenkian, 1995.

HILL, Jonathan. História do Cristianismo. Tradução de Raquel Kopit Cunha, Juliana A. Saad e Marcos Capano. Impresso e acabado em Cingapura. São Paulo: Edições Rosari, 2008.

JACOBOVICI, Simcha/PELlEGRINO, Charles. A Tumba da Familia de Jesus. A descoberta, a investigação e as provas que podem mudar a História. Prefácio de James Cameron. Tradução de Artur Neves Teixeira. Editora Planeta do Brasil, São Paulo, 2007.

KARDEC, Allan. O Evangelho Segundo o Espiritismo. 8. ed. Tradução de J. Herculano Pires. São Paulo: Edições FEESP, 1992.

KARDEC, Allan. O Livro dos Espíritos. 5. ed. Tradução de J. Herculano Pires. São Paulo: Edições FEESP, 1990.

KARDEC, Allan. A Gênese. 8. ed. São Paulo: Edições da Federação Espírita do Estado de Sâo Paulo, 1990.

KAUTSKY, Karl. A origem do cristianismo. Tradução, introdução, apêndices e outros de Luiz Alberto Moniz Bandeira. Rio de Janeiro: Editora Civilização Brasileira, 2010.

LARA PEINADO, Federico. Estudos preliminares y notas. In: POEMA de Gilgamesh. Anónimo. Traducido de la confrontación de diferentes ediciones de asiriólogos, com estúdio preliminar y notas por Federico Lara Peinado. Madrid: Editora Tecnos de Madrid, 1988.

Mc BRIEN, R. Catholicism. 3. ed. Londres: Editora Geoffrey Chapman, 1995.

NAVARRO, Júlia. A Bíblia de Barro [conspiração e morte no Iraque em busca pelo Livro Sagrado]. Tradução de Luís Carlos Cabral. Rio de Janeiro: Editora Ediouro, 2006.

PAES FILHO, Orlando. Angus: As Cruzadas. São Paulo: Editora Planeta do Brasil Ltda., 2005. 
PAGELS, Elaine. Além de toda crença: o Evangelho desconhecido de Tomé. [Beyond Belief: the secret golpel of Thomas]. Universidade Princepton. São Paulo: Editora Objetiva, 2003.

SCHMAUS, H. Teologia dogmática. Madrid: La Iglesia, 1966. t. 4.

SOUZA, Salmo Caetano de. A Igreja católica: forma de governo e regime político. Revista da Faculdade de Direito da Universidade de São Paulo, São Paulo, v. 102, p. 535-576, jan./dez. 2007.

TAVARES, Gérson Luiz. O Cristão Moderno. São Paulo: Edições Federação Espírita do Estado de São Paulo, 1992. 